\title{
雌雄ラット耳下腺のメトキサ之ンおよびピロカルピン刺激 唾液成分の加齢的変化について
}

\author{
福岡菌科大学茵科補緅学第一講座（指導：羽生哲也教授） \\ 福岡画科大学口腔生化学講座 (指導：阿部公生教授)
}

稲永昭虔

昭和 62 年 4 月 25 日受付

\section{Developmental Changes of the Composition in Parotid Saliva of Male and Female Rats in Response to Methoxamine and Pilocarpine \\ Akihiko Inanaga}

The First Department of Prosthodontics (Director: Prof. Tetsuya Habu)

Department of Oral Biochemistry (Director: Prof. Kimio Abe)

Fukuoka Dental College, Fukuoka, 814-01, Japan

Saliva secreted in response to $\alpha_{1}$-adrenergic and cholinergic receptor agonists such as methoxamine (Methox), $\alpha$-methylnoradrenaline, and pilocarpine (Pilo) was collected from the cannulated ducts of parotid glands of both male and female rats from 4 to 10 weeks and $3.5,8$, and 15 months of age. It was analyzed for volume, for the concentrations of protein, potassium, calcium, inorganic phosphate, and amino acid residues, and for the types of proteins, amylase activity and isozymes. After the collection of saliva, the parotid glands were carefully removed and weighed.

The wet weights of the glands increased substantially up to 8 weeks of age and then reached almost plateau values and finally tended to decrease at 15 months of age in both sexes. The salivary volumes secreted in response to Methox and Pilo were positively correlated with the parotid gland weights in both sexes. The concentrations of protein, potassium, and inorganic phosphate were inversely related to the salivary flow rates only at relatively low rates of flow in contrast that the amylase activity was positively correlated with the concentration of protein independent of the nature of the stimulus, age, and sex. In the $\alpha_{1}$-adrenoceptor stimulation, the amylase activity was positively correlated with the concentration of calcium independent of age and sex.

The types of protein, amino acid residues, and amylase isozymes did not show a great deal of differences at least qualitatively independent of the nature of the stimulus, age, and sex from 4 weeks up to 15 months of age. However, in parotid saliva of several rats at 8 and 15 months of age, the abnormal proteins were electrophoretically observed independent of the nature of the stimulus and sex. The relatively low molecular proteins in parotid saliva were selectively adhered to the resin plate regardless of the types of plate without polishing procedures in only dry states. 
Thus, it was conclusively elucidated that the secretory function of both $\alpha_{1}$-adrenergic and cholinergic receptors in the parotid glands of rats was complete at early stages and intact up to 15 months of age although some exceptions were observed in the protein secretion at elderly stages.

\section{Key words : Rat parotid saliva/Aging/Types of proteins /Electrolyte /Amylase / Resin plate}

\section{緒}

\section{言}

哽液腺は，腺房部，導管部，血管，自律神経，感覚神 経，筋上皮細胞抢よび結合織性の間質などで構成されて いる複雑な絸織である．ラット耳下腺の分化增殖と分泌 機能の開始は顎下腺や舌下腺より遅れて始まるが，成熟 化は疑下腺より早く, 出生後 25 日前後でほぼ完成するこ とが確認されている1ー13)。 また幼若ラットを用いて， 耳下腺内のアミラーゼ11や耳下腺スラィスの cAMP 量の変化やアミラーゼ分泌 ${ }^{14}$ '在測定したり，耳下腺外 導管を切断し，流出する唾没のナトリウムとカリウム量 を測定して，再吸収機能や自律神経系の完成時期 8,91 を，あるいは微小穿刺法を用いて再吸収機能やタンパク 質とアミラーゼの分泌 ${ }^{152}$ を観察した報告もみられるが， 導管切断で流出した，あるいは微小穿刺法で採取した厘 液には組織液の混入が考えられる。

一方, 成熟ラット耳下腺㗆液の性状に関する報告16一 23) には, 中高年龄ラットの耳下腺唾液の性状に関する 報告はほとんどみられない，耳下腺や顎下腺組織では， 中高年娍化に伴い脂肪化，結合織化，リンパ球やリンパ 組織の蓄積化，あるいは腫滪化などが生じるという報告 $24,25)$ や中高年齢化に伴い腺内のアミラーゼやタンパク 質の合成が低下, 特に分泌性タンパク質の合成能力が加 齢に伴い変化するという報告28-31)がある。乙れに対 し，中高年鈴になっても耳下腺の交感神経性 $\beta$ 一受容体 の機能や数は変化しないという報告13,26)もある. しか し分泌された在液タンパク質からてれらのこと在証明し た報告はみられない，さらに耳下腺の交感神経性 $\alpha$ 一受 容体の生理機能は， $\beta$ 一あるいはムスカリン性受容体の 場合と異なり，中高年龄になると変化すると報告 ${ }^{32-34}$ されているが，このことが耳下腺の兆液性状にどんな影 響を与えるかについての報告はみられない。ラット耳下 腺の加龄に伴う性差に関する報告も腺内のアミラーゼ ${ }^{351}$ ， 細胞周期 ${ }^{36)}$ および刺激の頻度と分泌在液量との関 係37)などに関する報告をみるだけである。

本実験では幼若時から中年路化至る雌雄ラットから交
感神経性 $\alpha_{1}$-受容体刺激薬であるメトキサそンと副交感 神経性受容体刺激薬であるピロカルピンを用いて純粋な 耳下腺唾液を採取し, その唾液中の主要パラメータを測 定することにより，乙れら受容体の分泌機能の加齿に伴 う変化を明らかにしようとした。このほかに義霜床用レ シンに付着する耳下腺棰液タンパク質の分析も行った。

\section{実験材料ならびに方法}

\section{I . 実験動物}

$4 \sim 8$ の各週踰， 10 週㢼， 3.5 月柃， 8 月齢および 15 月齢の Sprague-Dawley 系ラットで, 体重の近似す る 9 〜 15例ずつをそれぞれ 1 群として使用した．固型飼 料（オリエンタル醅母， MF，東京）と水道水を自由に 与え， 3.5 週舲までは親と同居させた．飼育室は日内リ ズムの影響をなくすために12時間の明暗周期とし, 消灯 は午後 6 時に行った。 各週および各月齢に達したラット は遅くとも1〜2 日後には実験に用いた。ただし，ピロ カルピン塩酸塩 (半井, 京都, 以下, Pilo と略記, $8 \mathrm{mg} /$ 体重 $\mathrm{kg}$ ) 刺激の 4 週齢の雌では, 2 日後でも国 液採取ができなかったので，4 日後に採取した，厘液採 取日には午前 9 時から午後 5 時まで絶食させ，水道水だ けを与えた。

\section{II．分泌刺激薬および遮断薬}

交感神経性 $\alpha_{1}$-受容体（ $\operatorname{Re}$ と略記）刺激薬にはメト キサミン篮酸塩 (メキサン注射液, 日本新薬, 京都, Methox 々略記, $6 \mathrm{mg} / \mathrm{kg}$ ) および $\alpha$ おチルノルア ドレナリン塩酸塩 (Regis, U.S.A., $\alpha$-mNA と略 記, $20 \mathrm{mg} / \mathrm{kg}$ ) 用いた。副交感神経性 Re の刺激薬 として Pilo 孝用いた。このほかに8 月齢ラットの耳下 腺睡腹のタンパク質成分の刺激差を比較観察するため に，Table 1 に示した各種 Re 刺激薬を用いた。ま た，4 週踰から15月兆に至るラット耳下腺の厘液分泌の 抑制実験から，交感神経性 $\alpha_{1}$-および副交感神経性 $\mathrm{Re}$ の機能変化を観察するために，各種の $\operatorname{Re}$ 遮断薬を用 いた（Table 1)。なお，各刺激薬および遮断薬は規定 の用量を腹腔内に 1 回投与したが，遮断薬は刺激薬投与. 
Table 1 The different types of the autonomic agonists and antagonists

\begin{tabular}{l|c|l|l}
\hline Agonist and antagonist & Dose $(\mathrm{mg} / \mathrm{kg})$ & Selectivity & Company (Location) \\
\hline 1. Isoproterenol & 30 & Non-selective $\beta$-receptor & Nakarai (Kyoto) \\
2. Terbutaline & 8 & $\beta_{2}$-receptor & Fujisawa(Osaka) \\
3. Clonidine & 5 & $\alpha_{2}$-receptor & Tokyokasei(Tokyo) \\
4. Phenoxybenzamine & 25 & $\alpha_{1}$-and $\alpha_{2}$-receptor & Tokyokasei (Tokyo) \\
5. Phentolamine & 25 & $\alpha_{1}$-and $\alpha_{2}$-receptor & Cibagaigy (Hyogo) \\
6. Dihydroergotamine & 25 & $\alpha_{1}$-and $\alpha_{2}$-receptor & Tokyokasei(Tokyo) \\
7. Atropine & 1 & Nicotinic receptor & Merck (Germany) \\
8. Propranolol & 10 & Non-selective $\beta$-receptor & Sumitomokagaku(Osaka) \\
\hline
\end{tabular}

$1-3$, Agonist ; 4-8, Antagonist.

の15〜30分前に投与した。

\section{III. 耳下腺湴液の採取}

体重測定後, ラット腹腔内にペントバルビタールナト リウム塩 (Nembutal, Abbott 社, U.S.A., $50 \mathrm{mg}$ / kg）を注射して麻酔したのち，セロテープでラットの 四肢を板に張り付けて仰㸝位に固定した。ついで唾液採 取中の乎吸困難を防止するためにラットに気管切開を施 した。

耳下腺睡淮の採取は, Abe ら (1975) 16)の報告に往 い，耳下腺外導管開口部に細いポリエチレンチューブ (PE 10, Clay Adams 社, U.S.A.) 在挿人 (Fig. 1) し, 各種の刺激条件下に分泌する睡液を採取した。分泌 哽液量は, 15分間の採取臣液を重量既知の小試験管内に 集め, 比重1.00とみなして科量によって決定した。

IV . 腺湿重量の测定

重液採取の終了後, 幽側耳下腺部を開き, 脂肪組織と 外導管部を取り除いた。つぎ両側の腺体を摘出し，た だちに腺湿重量を測定した。

$V$. 唾液成分の分析

A . 総タンパク質量の测定

総タンパク質量の測定は, Lowry ら (1951) 43)の方 法を一部改変した Dawes（1965）44'の方法を用い，標 準タンパク質には，唾液タンパク質に最も近似した定量 值が得られるカゼイン (Hammarsten, Merck,

Germany）を使用した。

B.アミフーゼ活性の測定

アミラーゼ活性はブルーデキストランを用いるアミラ 一ゼ活性試験法（1971）45) によって測定した。

C . カリウム, カルシウムおよび無機りン酸濃度の測 定

唓液中のカリウムとカルシウムは Dawes $\left(1967^{46)}\right.$ ，

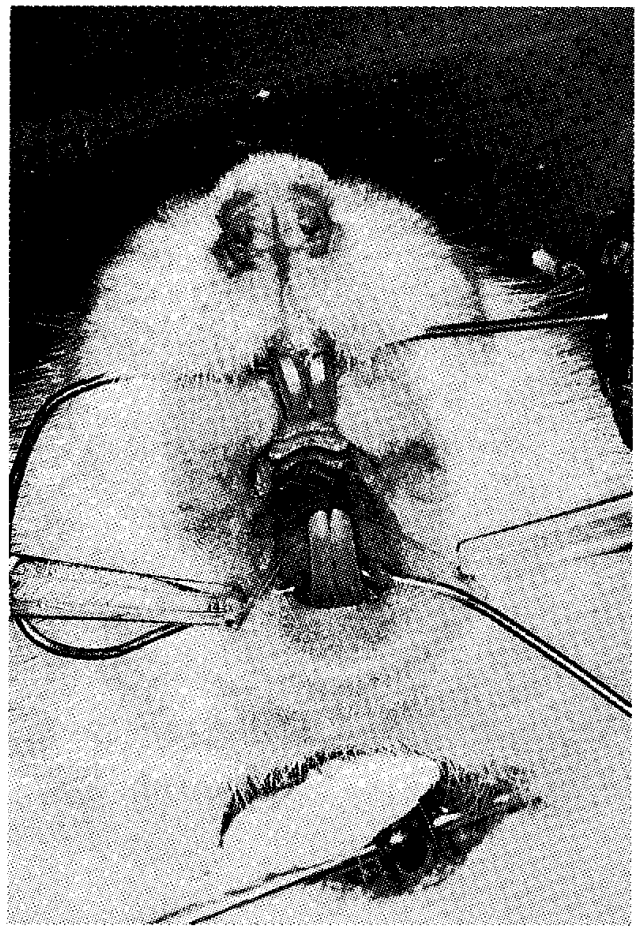

Fig. 1 The photograph of a rat collecting parotid saliva with thin polyethylene tubes (PE-10) from both parotid gland ducts

$1969^{47)}$ ) の方法に従い，原子吸光分光光度計を用いて 定量した。無機リン酸濃度は Chen ら (1956) ${ }^{48}$ の方 法で测定した。

D. 各種電気泳動法

電気泳動用の各タンパク質試料は，カルシウム結合性 タンパク質の沈殿を防止するために ${ }^{49} 1 \mathrm{M}$ の

$\mathrm{Na}_{3}$-EDTA (pH 8.6) を加え, $-80^{\circ} \mathrm{C}$ で凍結保存し た。これを，蒸留水で24時間透析したのち，凍結乾燥粉 末にした。必要に応じて, 一定のタンパク質濃度に再溶 
解したのち，各種の電気泳動およびアミノ酸分析の試料 とした.

電気泳動法は以下の方法を用いた。すなわち塩基性と 酸性の7.5\%のポリアクリルアミドゲルを用いる

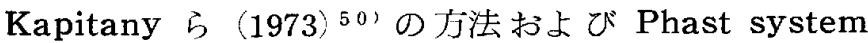
(Pharmacia, Sweden)の Native (Gradient ゲル10 〜15\%), SDS (Gradient ゲル10〜15\%) および pH 3 〜 $53 \sim 9$ のH 勾配の等電点 $(\mathrm{IEF})$ 電気泳動法で ある・

アミラーゼのアィソザィムの検出は Murata ら(19 86) ${ }^{51 \prime}$ の報告に準じ, Phast system $の \mathrm{pH} 3 \sim 5$ の等 電点電気泳動法で各アイソザイムを分離したのち，アミ ラーゼ活性染色を行った。なお，試料のタンパタ質量は, Kapitany ら $(1973)^{50 \prime}$ の方法では $150 \mu \mathrm{g} /$ カラムであ ったが，Phast systemでは1 $1 \mu \mathrm{g} /$ てンを用いた。

E。ゲルの染色

Kapitany ら (1973）50の酸性および䁌基性ゲルの染 色にはAbeら (1978)17)の報告に従い, Wool fast blue と Fast green 用いた. Phast system で は，銀染色を行った。

\section{F.ア之人酸分析}

前述の方法で調製した，24時間透析後の涷結乾燥 粉末 $2 \mathrm{mg}$ ⿸ $2 . \mathrm{cml}$ の $6 \mathrm{~N} \mathrm{HCl}$ に溶解したのち, 加水分解時間の影響をなくすために各試料ごとに $24 ， 48$ および72時間の加水分解を行い，これら 3 つ の試料の結果からそれぞれの平均值を求めた，加水 分解は脱酸素後, 約 $115^{\circ} \mathrm{C}$ で行った。 その後, $50^{\circ} \mathrm{C}$ で $\mathrm{HCl}$ を完全に蒸発させたのち，2 ml の0.001 N $\mathrm{HCl}$ で再溶解させたものをアミノ酸分析用試料と した.アミノ酸分析は, Amino acid analyzer (LKB，4151，Sweden）有いた。

G. 唾液タンパク質付着実験用レジン試験片の作製 レジン試験片には，加熱重合型の Acron $(\mathrm{G}-\mathrm{C})$ お よび流し込み型の Palapress (Kulzer) を用いた。

前述の各レジン片は，一片 $14.0 \mathrm{~mm}$ の正方形で，厚さ は $1.5 \mathrm{~mm}$ である. 試験片の片面は，レシン床の研暦面 を想定して鏡面仕上げにしているのに対し，反対面は瀶 床に即して石高面から分割したままで，雨面とも一切研 䄷操作を加えていない。しかし側面だけは耐水ペーパー の\#600で一㞗だけ研磨した。

H .レジ試験片に付着したタンパク質の同定

8 月齢の雄ラットから Pilo 刺激唾液を $400 \mu 1$ 採取し,

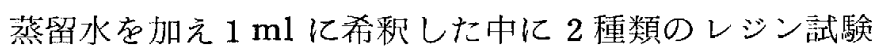
片を 1 片ずつ浸漬した，続いて浸漬液を $37^{\circ} \mathrm{C}$ の餧卵器
内で乾燥しないように密封して 1 週間保存するか， 1 週 間かけて徐々に乾燥させた。この結果, 前実験ではレジ ン試験片に付着するタンパク質が，極く微量であった が，後の実験ではタンパク質が付着したので，てのう法 を採用した。前述のラットから唾液を $2 \mathrm{ml}$ 採取し, 蒸 留水で $5 \mathrm{ml}$ に希釉して 2 種類のレジン試験片を 15 片ず つ浸漬した。小崡ブラシで剝離し，蒸留水に溶かし込ん だ付着タンパク質を24時間透析し，凍結乾燥粉末にして Phast system の Native (Gradient ゲル 10〜15\%) 電気泳動法でタンパク質成分の分析を行った。

\section{成}

I．ラットの体重，耳下腺の湿重量および唾液分泌特 性の加齢的変化と性差

A . 体重扔よび腺湿重量の加齢的変化と性美

ラットの加齢による体重ならびに腺檪重量の変動を Fig. 2 に示す。体重は， 4 週歯では性差が認められな

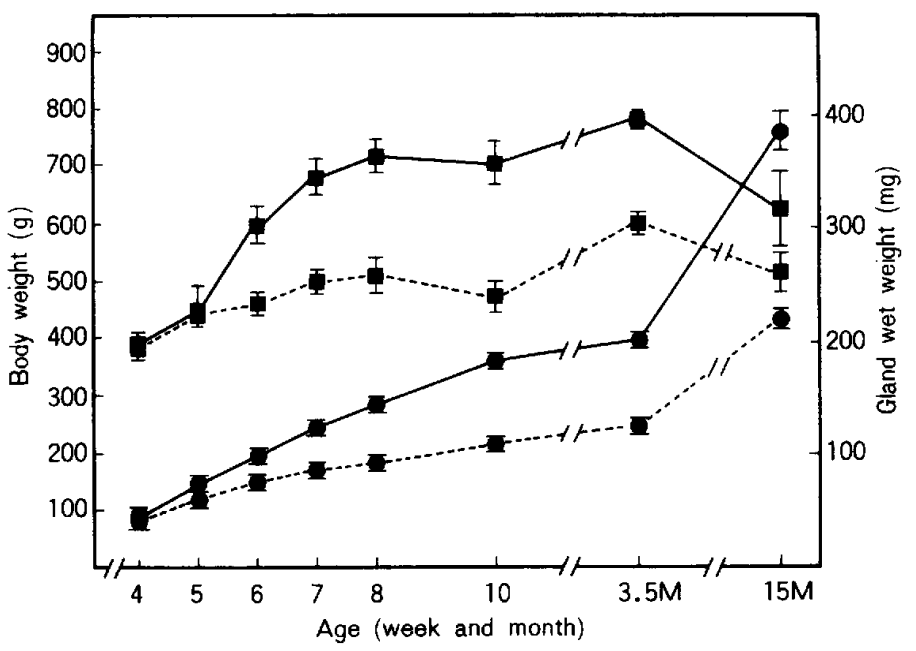

Fig. 2 Changes of body weight and weights of the parotid glands of male and female rats from 4 weeks to 15 months of age

$\longrightarrow$, Body weight of male rats ;

---- , One of female rats;

$\longrightarrow$, Gland wet weights of male rats ;

----, Ones of female rats.

かったが， 5 週齢から雄の体重増加が顕著で10週齢で雌

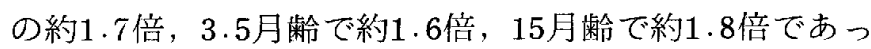
た.

腺湿重量は，5週齢まで性差はなかったが 6 週柃から 明暸な性差が羿められた（Fig，2）。雄では 5 〜 週 


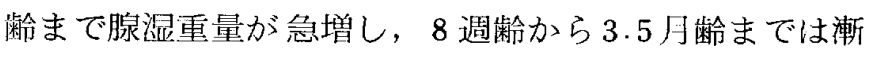
增した。しかし雌雄とも15月龄では耳下腺の腺湿重量は 減少し，6 週齢の值まで減少した。政では雄と類似の増 加傾向を示したが，増加率は非常に少なかった。

B. Methox および Pilo 刺激に対する分泌応答の加 歯的変化子性差

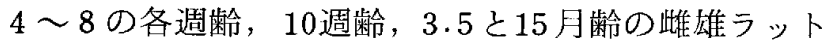
に Methox と Pilo t投与して, 分泌機能の加齢的変化 そ性差を検索した結果を Figs. $3 \sim 9$ 抢よび Table 2 に示した。

\section{a．分泌海液量と分泌速度の変動}

分泌唾液量 $(F i g .3)$ は採取時問 15分の唾液量 $(\mu \mathrm{l})$ を示し，また分泌速度は単位腺湿重量当たり 1 分間の分 泌量 $(\mathrm{nl} / \mathrm{mg}$ 腺湿重量 $/ \mathrm{min}$ ) を測定した。

Methox 刺激の分泌在淮量は, 雄では, 分泌開始の 4 週齢から3.5月齢にかけて漸增し，3.5月齢で最高值を 示した. 15月秢になると顕著に減少し，4 週龄の值上り 低くなった。雌では 5 週齢で最高值を示したのち加齢と ともに漸減し，15月歯では同月齢の雄の值に近似した。 Pilo 刺激の場合では，雄は 7 週秢まで増加したが，こ れ以降は15月齢まで plateau を形成した。雌は 10 週㱓 まで漸増し，その後は15月齢まで plateau を形成し た。また，分泌庶液量の有意な加齢差および性养はPilo 刺激の場合にのみ認められた（Table 2).

腺湿重量と分泌俥液量の相関を Fig. 4 亿示す。両者 は刺激の種類，年齢および性別に関係なく， $\mathrm{Y}=0.8 \mathrm{x}$ 一 $25.0(\mathrm{r}=0.583, \mathrm{P}<0.01)$ の順相関を示した。

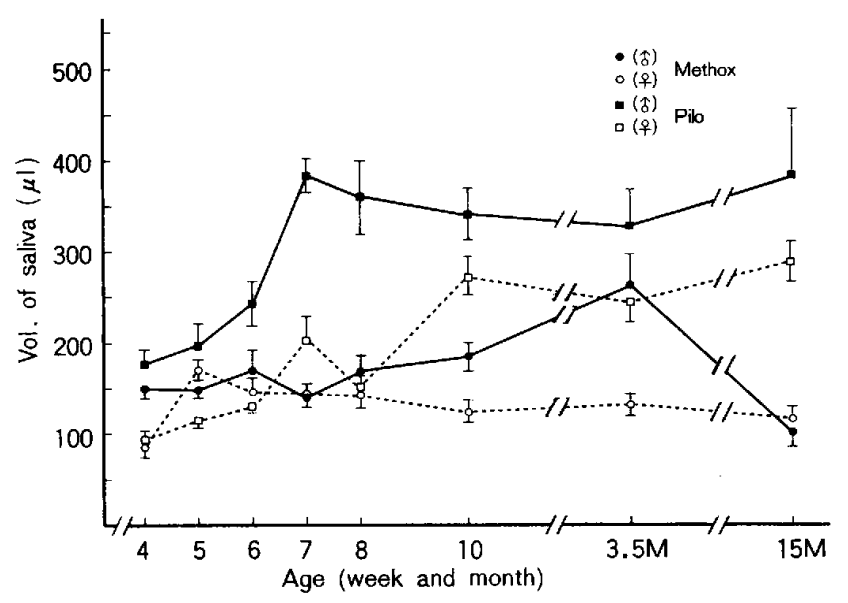

Fig. 3 Changes of the salivary volume secreted by the parotid glands of male and female rats from 4 weeks to 15 months of age in response to methoxamine and pilocarpine

-, Methoxamine-stimulated parotid saliva of male rats ;

$\circ$, Methoxamine-stimulated parotid saliva of female rats ;

-, Pilocarpine-stimulated parotid saliva of male rats ;

$\square$, Pilocarpine-stimulated parotid saliva of female rats ;

All symbols are also applicable to Figs. $4-18$.

Table 2 Two way analyses of variances of age and sex effects on the developmental changes of several parameters in parotid saliva of rats

\begin{tabular}{l|c|c|c|c}
\hline \multirow{2}{*}{ Factor } & \multicolumn{2}{c|}{$\begin{array}{c}\text { In methoxamine- } \\
\text { stimulated saliva }\end{array}$} & \multicolumn{2}{c}{$\begin{array}{c}\text { In pilocarpine- } \\
\text { stimulated saliva }\end{array}$} \\
\cline { 2 - 3 } & A & B & A & B \\
\hline Vol. of saliva & N.S. & N.S. & $\mathbf{P}<0.01$ & $\mathbf{P}<0.01$ \\
Salivary flow rate & N.S. & N.S. & N.S. & N.S. \\
Protein concentration & N.S. & N.S. & N.S. & $\mathbf{P}<0.01$ \\
Protein secreted $(\mathrm{mg} / \mathbf{h})$ & $\mathbf{P}<0.05$ & $\mathbf{P}<0.05$ & $\mathbf{P}<0.01$ & $\mathbf{P}<0.05$ \\
Amylase activity & $\mathbf{P}<0.05$ & N.S. & $\mathbf{P}<0.05$ & $\mathbf{P}<0.01$ \\
Potassium concentration & N.S. & N.S. & N.S. & $\mathbf{P}<0.01$ \\
Calcium concentration & N.S. & N.S. & N.S. & N.S. \\
Inorg. P. concentration & N.S. & N.S. & N.S. & $\mathbf{P}<0.05$ \\
& N.S. & P $<0.05$ & N.S. & N.S.
\end{tabular}

Factor $\mathrm{A}$ and $\mathrm{B}$ denote age and sex differences respectively by ANOVA 


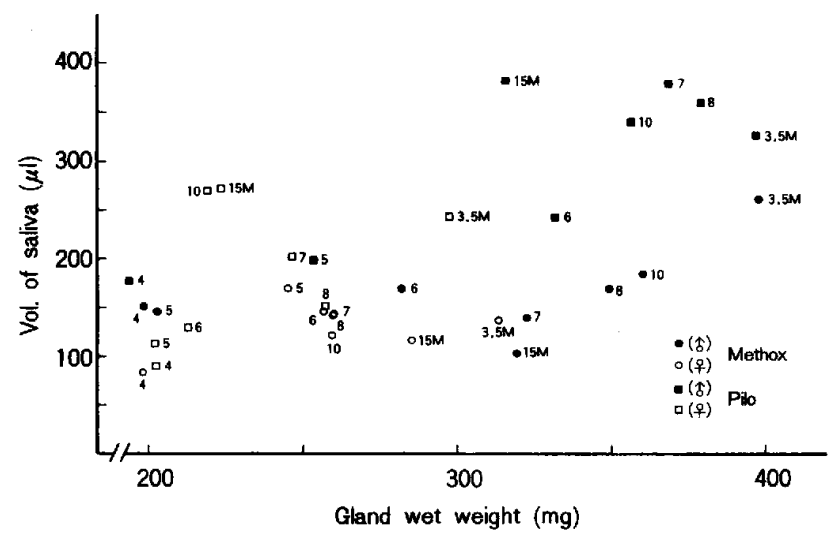

Fig. 4 Relationships between volume of saliva secreted and the weights of the parotid glands of male and female rats in response to methoxamine and pilocarpine

Numbers in figures $(4,7,11,12$, 14,16 , and 18) denote the weeks and months (3.5 M and $15 \mathrm{M})$ of age.

唾液の分泌速度の変化（Fig.5）は，Methox およ び Piloによる両刺激の雌では分泌量変化と類似した。

しかし, 両刺激の雄は, 6 週粭では分泌量の増加とは逆 に，速度が遅くなる傾向を示した。乙の時期は腺湿重量 が急増した時期である．また，両刺激唾液の分泌速度に は統計的に有意な加羭差および性差は認められなかった (Table 2).

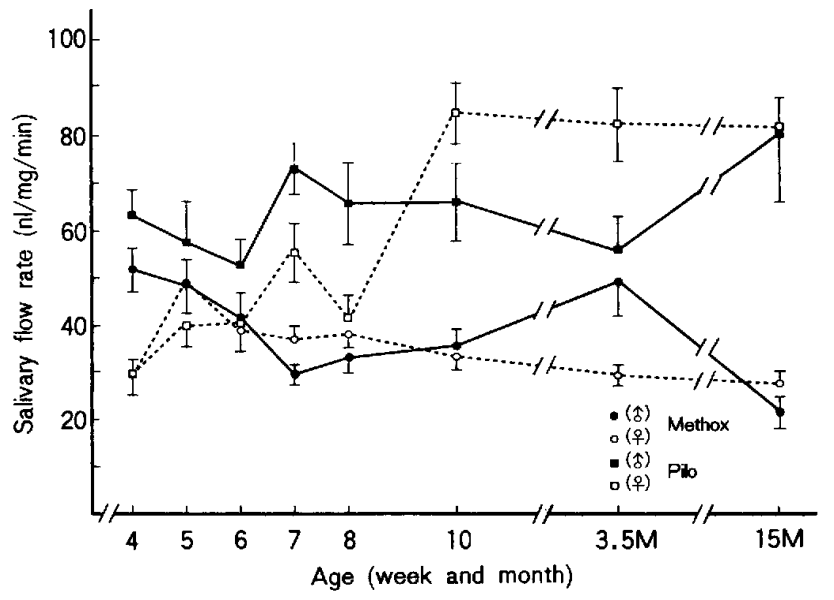

Fig. 5 Changes of the salivary flow rates secreted by the parotid glands of male and female rats from 4 weeks to 15 months of age in response to both stimuli b .タンパク質濃度と分泌タンパク質量の変動

タンパク質濃度（Fig. 6) は，Methox 刺激の䧳雄 および Pilo 刺激の雄はともに類似の推移を示し加齿と ともに漸増し，15月齢で最高值を示した。しかし Pilo 刺激の雌は10週噛まで変動が大きかった。また，Pilo 刺激の場合には，各年齢とも雌のほうが有意に高い值を 示した（Table 2).

唾液分泌速度とタンパク質濃度の相関を Fig. 7 に示 す. 刺激の種類，年齢および性別を考えず，Pilo 刺激 の雌を除いた場合の回㷌直線は， $\mathrm{Y}=0.05 \mathrm{x}-1.4 （ \mathrm{r}=$ $0.812, \mathrm{P}<0.001)$ を示した. Methox 刺激の雌雄だけを

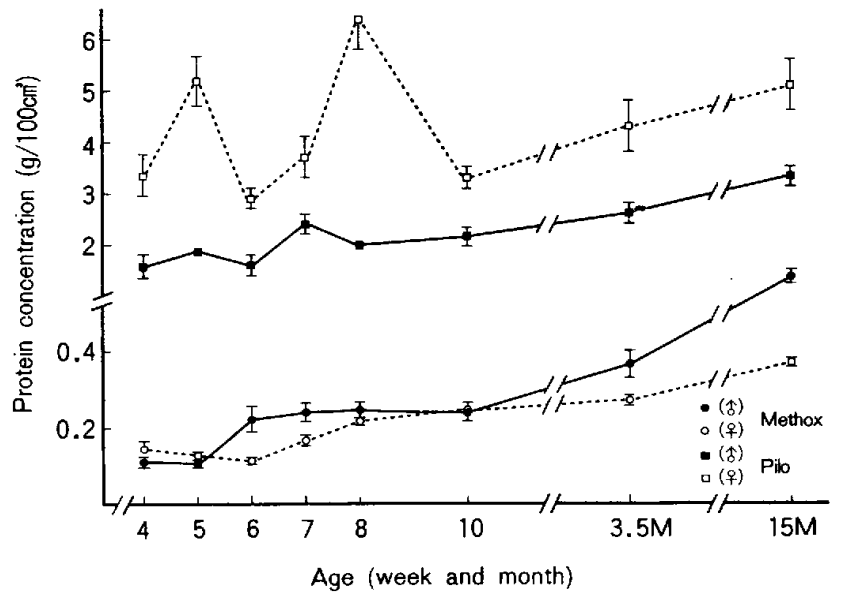

Fig. 6 Changes of protein concentration in parotid saliva of male and female rats from 4 weeks to 15 months of age elicited by both stimuli

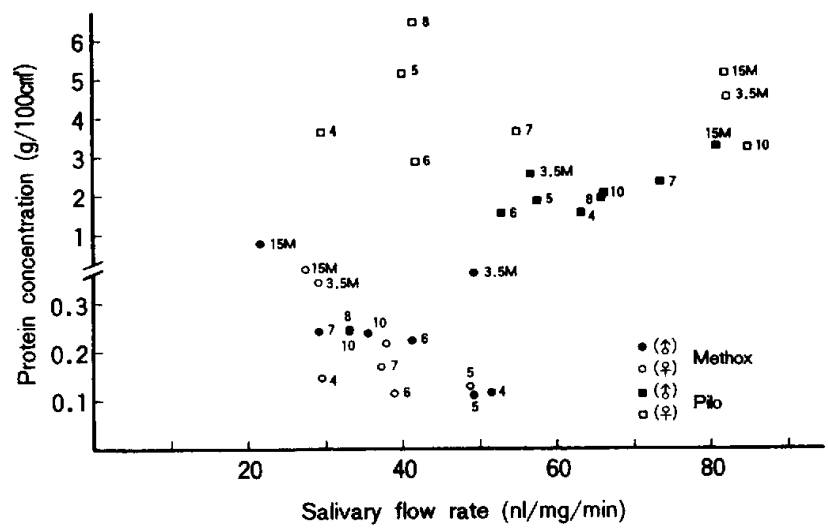

Fig. 7 Relationships between protein concentration and flow rate of the parotid glands of male and female rats in response to methoxamine and pilocarpine 
併せた場合の相関は， $\mathrm{Y}=-0.01 \mathrm{x}+0.7(\mathrm{r}=-0.579$, $\mathrm{P}<0.03)$ の逆相関を示し, Pilo 刺激の雄は $\mathrm{Y}=0.04 \mathrm{x}$ $-0.5 （ \mathrm{r}=0.692, \mathrm{P}<0.07)$ と順相関の傾向を示した が，雌はほとんど相関しなかった。

$\mathrm{mg} / \mathrm{h}$ で表示した分泌タンパク質量 (Fig. 8) の比 較ではいずれの場合も加齢により増加した。単位腺湿重 量当たりの分泌タンパク質量 $(\mu \mathrm{g} / \mathrm{mg} / \mathrm{h}$, Fig. 9) も， $\mathrm{mg} / \mathrm{h}$ の結果と同様の傾向を示した，両表示 $(\mathrm{mg} / \mathrm{h}$ および $\mu \mathrm{g} / \mathrm{mg} / \mathrm{h})$ の分泌タンパク質量には，Methox 刺激の分泌タンパク質量 $(\mu \mathrm{g} / \mathrm{mg} / \mathrm{h})$ に性差が浔めら

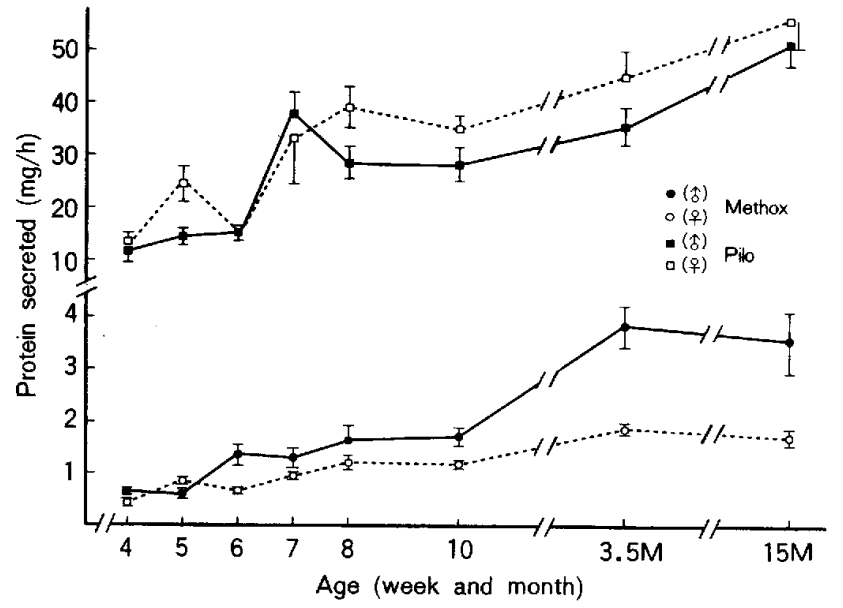

Fig. 8 Changes of the amounts $(\mathrm{mg} / \mathrm{h})$ of protein secreted by the parotid gland of male and female rats from 4 weeks to 15 months of age in response to both stimuli

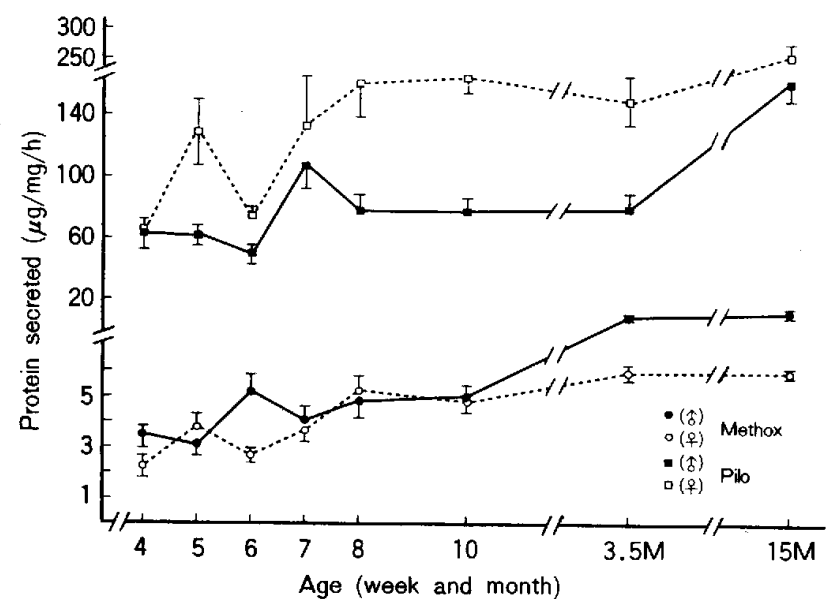

Fig. 9 Changes of the amounts $(\mu \mathrm{g} / \mathrm{mg} / \mathrm{h})$ of protein secreted by the parotid gland of male and female rats from 4 weeks to 15 months of age in response to both stimuli
れなかったてとを除けば，そのほかはいずれも加齢差お よび性差が認められた（Table 2)。

c .アミラーゼ活性の変動

アミラーゼ活性の加齢的变化を Fig. 10亿示す.アミ ラーゼ活性は Figs. 11，12，16も同様に対数值で示し ている．両刺激の雄は，ともに類似の加齢的変化を示 した. $5 〜 7$ 週齿泫アアラーゼ活性が低下したが，そ の後の年齢ではほぼ plateau を形成した.Pilo 刺激の 雌では，加踰によるアミラーゼ活性の変動はほとんど 認められなかったが，Methox 刺激の場合には 7,8 および10週齢でアミラーゼ活性が低下した。また Pilo 刺激の場合だけに統計的に有意な性差が認められた。 しかし，両刺激の加齢差は統計的に有意ではなかった (Table 2).

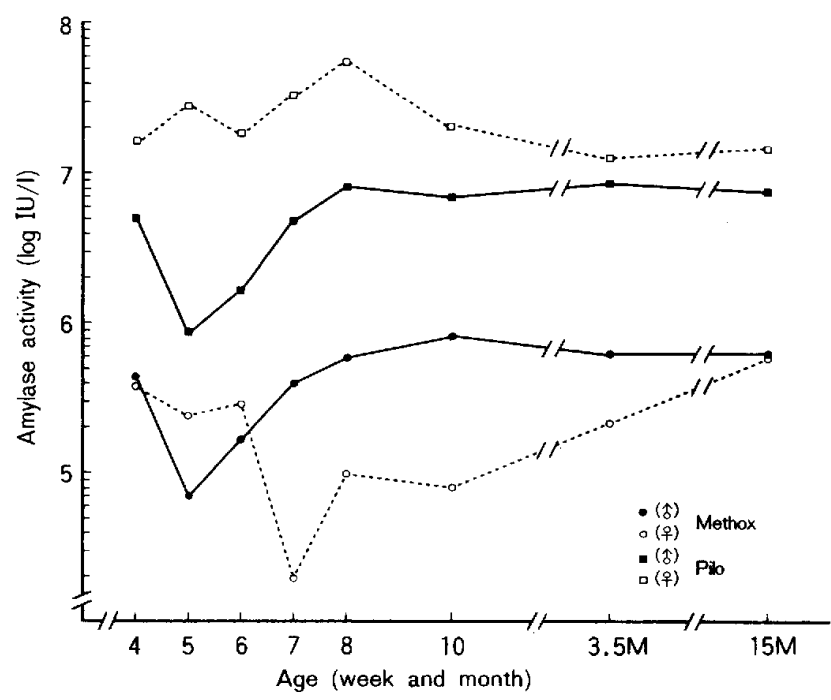

Fig. 10 Changes of amylase activity expressed logarithmically in parotid saliva of male and female rats from 4 weeks to 15 months of age in response to both stimuli

腺湿重量とアミラーゼ活性の相関を Fig. 11 に示す. Methox 刺激の雄は順相関の傾向 $(r=0.692, \quad P<0.07$ を示したのに刘し，雌打よび Pilo 刺激の雌雄はいずれ も有意な相関を示さなかった。また，アミラーゼ活性と 分泌速度の相関図は Fig．７亿類似していた（Fig．省 略)．タンパク質濃度とアミラーゼ活性の相関を Fig.12 に示す．刺激の種類，年齿，性別を考えず，全被験年齢 の相関（Fig．12）を検討したところ， $\mathrm{Y}=0.4 \mathrm{x}+5.4$ $(\mathbf{r}=0.849, \quad \mathbf{P}<0.001)$ で有意に高い順相関を示した . しかし，各刺激の雌雄個別の相関には有意差は得られな 


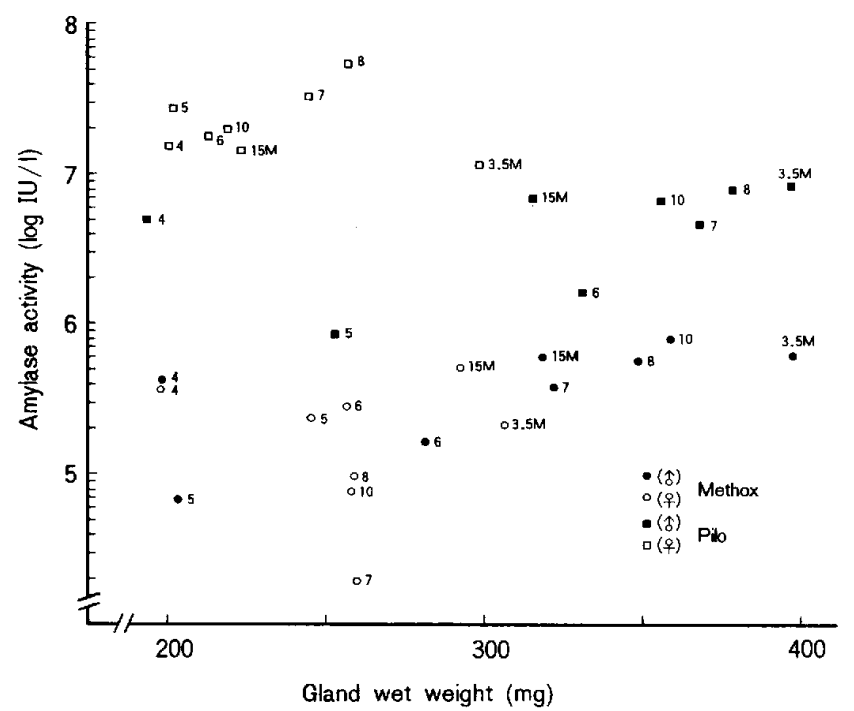

Fig. 11 Relationships between amylase activity expressed logarithmically and the weights of the parotid glands of male and female rats in response to methoxamine and pilocarpine

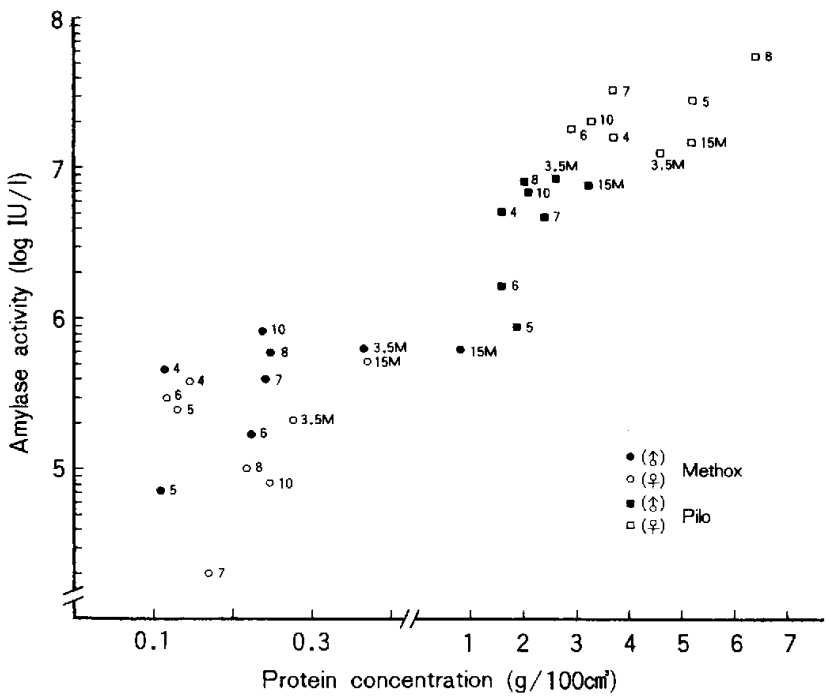

Fig. 12 Relationships between amylase activity expressed logarithmically and protein concentration of the parotid glands of male and female rats in response to methoxamine and pilocarpine

かった。

\section{d．カリウム $(\mathbf{K})$}

K濃度の加秢的変化を Fig. 13 に示す. Methox 刺 激の雄は各年齢ごとに変動の激しいてとが認められた。 Pilo 刺激の雄は $4 \sim 5$ 週路にかけて $63.8 \%$ 減少したの ち，15月齢までわずかに増加した．15月柃では10週秢の

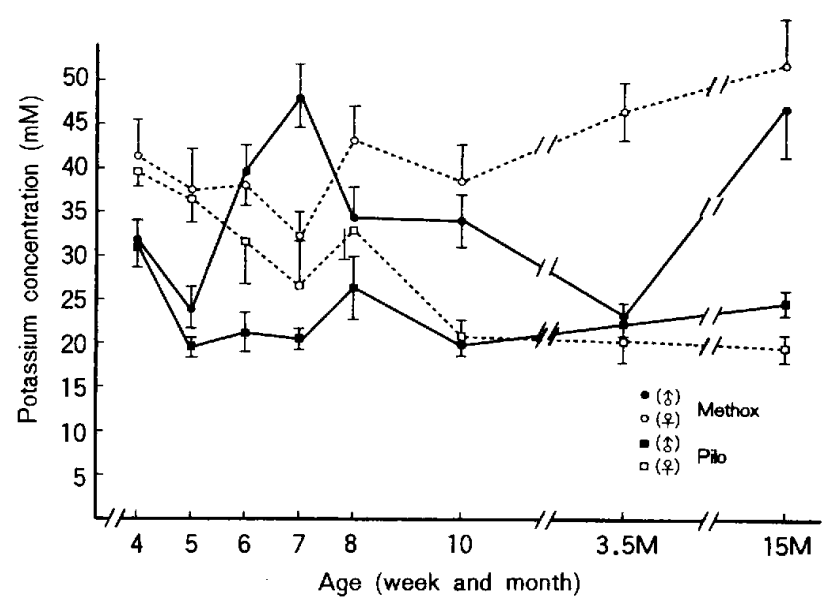

Fig. 13 Changes of the concentration of potassium in parotid saliva of male and female rats from 4 weeks to 15 months of age in response to both stimuli

值に比較して $36.1 \%$ 増加した。両刺激の雌は 8 週粭まで 類似した変動を示したが，10週齢以降では Methox 刺 激は増加傾向，Pilo刺激は減少傾向を示した。また統計 的に有意な加齢差および性差は得られなかった（Table 2 ).

唾液分泌速度とK濃度の相関を Fig. 14に示す. 刺激 の種類，年歯および性別を考えない場合の相関関係は， $\mathrm{Y}=-0.5 \mathrm{x}+54.2(\mathbf{r}=-0.837, \mathrm{P}<0.001)$ で，有意な 逆相関を示した。しかし各刺激を個別に検討した場合, Methox 刺激の雄は $\mathrm{Y}=-0.7 \mathrm{x}+63.1 \quad \mathrm{r}=-0.828$, $\mathrm{P}<0.03)$ と有意な逆相関を示したが，雌では有意な相

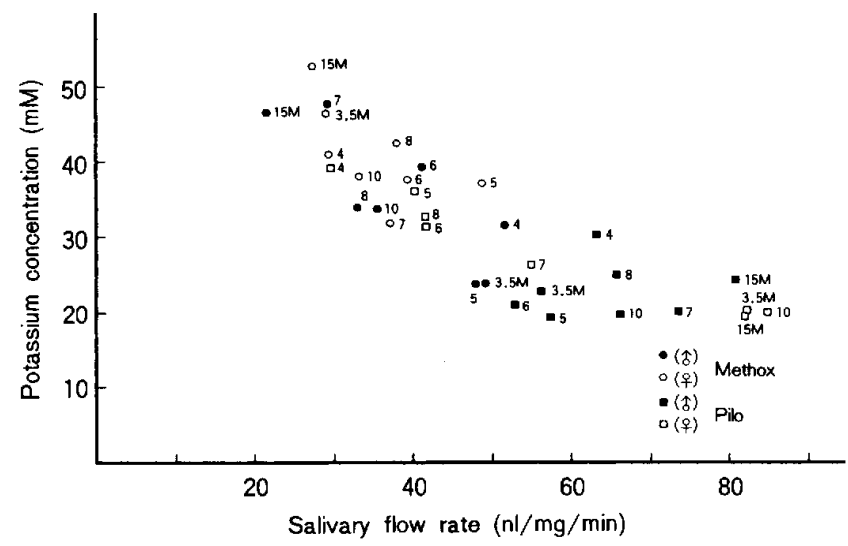

Fig. 14 Relationships between potassium concentration and flow rate of the parotid glands of male and female rats in response to methoxamine and pilocarpine 
関 $(\mathbf{r}=0.630, \mathrm{P}<0.10)$ は得られなかった. Pilo 刺激の 䧼も有意な相関は認められなかったが，雌は $\mathrm{Y}=-0.3 \mathrm{x}$ $+47.9(\mathrm{r}=-0.971, \quad \mathrm{P}<0.02)$ で有意な逆相関を示し た。

\section{e 。カルシウム $(\mathrm{Ca})$}

$\mathrm{Ca}$ 濃度の加歯的変化を Fig. 15に示す. Methox 刺 激の雄と Pilo 刺激の雌および Methox 刺激の雌と Pilo 刺激の雄は, 類似の加齢的変化を示した。すなわち, 前 者群では 5 週齢で一度減少後に 7 〜 週齢まで増量した が，その後に減少し，その減少した値でほぼ plateau を形成した。後者群では10週粭まで漸诚後に15月跲まで 漸增した。しかし， Ca 濃度には雨刺激とも，統計的に 有意な加齢差は認められなかったが，Pilo 刺激の場合 には性差が認められた（Table 2)。

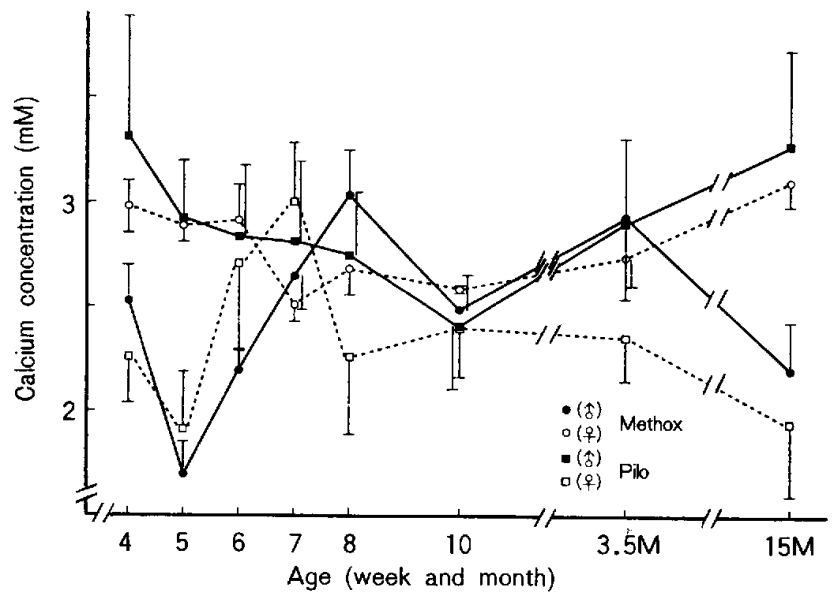

Fig. 15 Changes of the concentration of calcium in parotid saliva of male and female rats from 4 weeks to 15 months of age in response to both stimulj

Ca 濃度とアミラーゼ活性の相関を Fig. 16 亿示す。 両者の相関は Methox 刺激では極めて高かった。すな わち, Methox 刺激では, 雄は $\mathrm{Y}=0.6 \mathrm{x}+4.0\langle\mathrm{r}=0.749$, $\mathrm{P}<0.05 ）$ 示し, 雌は $\mathrm{Y}=2.1 \mathrm{x}-0.6 （ \mathrm{r}=0.928$, $\mathrm{P}<0.02 ）$ を示した. しかし Pilo 刺激の雌雄には有意 な相関は認められなかった。

\section{$\mathbf{f}$. 無機リン酸 $(\mathbf{P i})$}

$\mathrm{Pi}$ 濃度の加齢的変化を Fig. 17 亿示す. Methox 刺 激の雄では 10 週粭までに増加が注ぼ終了するが，雌は 3.5 月齢以降も増加傾向が続き，15月撂の 值は 10 週秢に 比較して $50.0 \%$ 增加した. しかし, Pilo 刺激の雌にの み特異的な動きが認められた。すなわち 5 〜 週噃まで

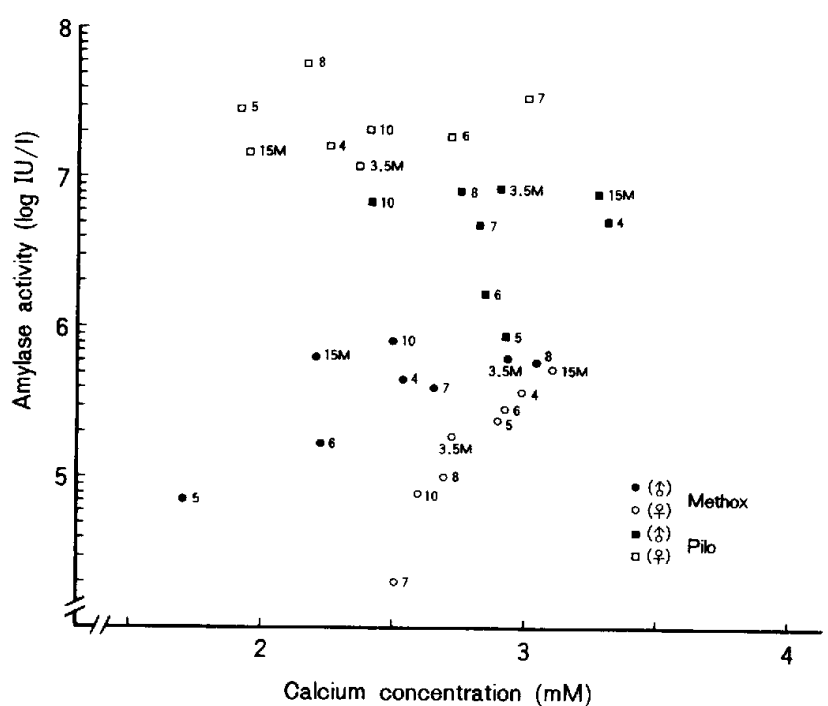

Fig. 16 Relationships between amylase activity expressed logarithmically and calcium concentration of the parotid glands of male and female rats in response to methoxamine and pilocarpine

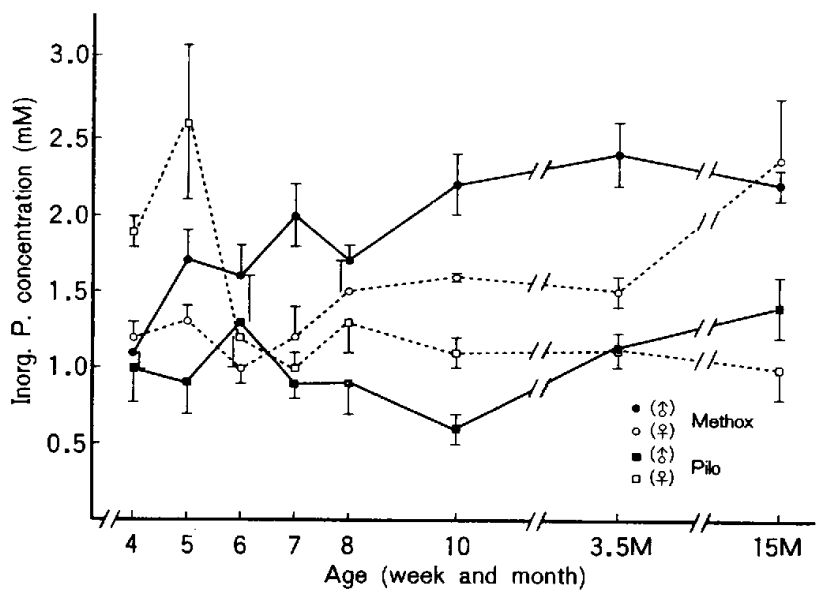

Fig. 17 Changes of the concentration of inorganic phosphate in parotid saliva of male and female rats from 4 weeks to 15 months of age in response to both stimuli

急激に減少するが， 6 週齢から15月㐘命まではほとんど変 化がなく，幼若時に高い $\mathrm{Pi}$ 濃度を示した，雄の場合 には，6 週齢を除くと，10週齢まで漸減し，その後15月 齢まで増加した。しかし，両刺激とも，統計的に有意な 加料会差は認められなかったが, Methox 刺激にのみ性差 が認められた（Table 2).

睡液分泌速度と Pi 濃度の相関を Fig. 18 亿示す. 
刺激の種類，年齢および性別を考えず，分泌速度が $65 \mathrm{nl} / \mathrm{mg} / \mathrm{min}$ 以下の相関関係は $\mathrm{Y}=-0.02 \mathrm{x}-2.6(\mathrm{r}=$ $-0.542, \mathrm{P}<0.01)$ となり有意な逆相関を示した。しか し, 分泌速度が $65 \mathrm{nl} / \mathrm{mg} / \mathrm{min}$ 以上では $\mathrm{Y}=0.02 \mathrm{x}-0.7$ $(\mathbf{r}=0.735, \mathrm{P}<0.05)$ となり $\mathrm{Pi}$ 濃度は分泌速度に有意 な順相関を示した。しかし，両刺激とも雌雄を別々に検 詩した場合には，有意な相関関係は得られなかった。

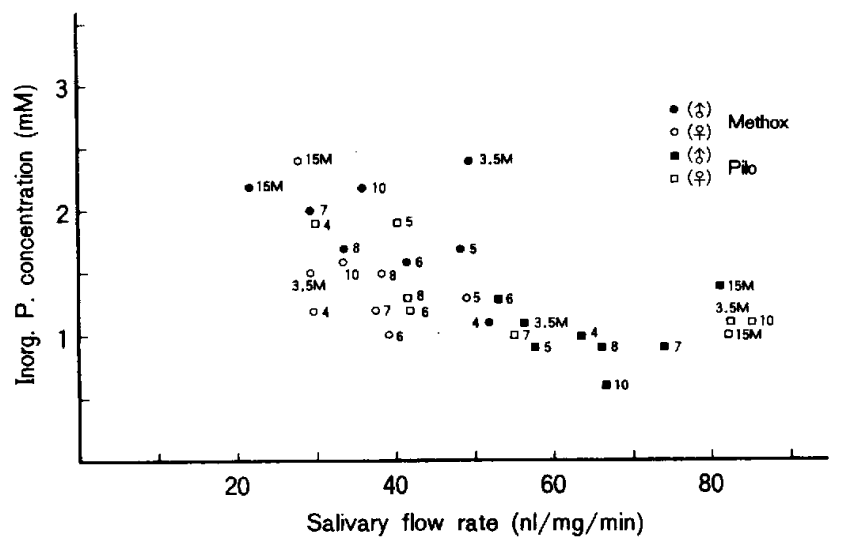

Fig. 18 Relationships between inorganic phosphate concentration and flow rate of the parotid glands of male and female rats in response to methoxamine and pilocarpine

II. 棰液のタンパク質成分, アミラーゼアイソザイム パターン, およびアミ, 酸組成の加喻的変化, 性差 および刺激差

A. 㗆液のタンパク質成分の変化

Methox 抢よび Pilo 刺激耳下腺唾液のタンパタ質成 分の加齢差, 性差および刺激差を, 各種の電気泳動法を 用いて検索した，タンパク質成分は代表例を Figs. 19 〜22に示した，低い pH 域の IEF 像（Fig. 21）に個体 差が認められた以外は, 顕著な加齢差, 性差および刺激 差は観察できなかった。また，各種の $\operatorname{Re}$ 刺激薬すなわ ち，交感神経性 $\beta$ 一， $\beta_{2} 一 ， \alpha_{1}$ 一および $\alpha_{2}-\operatorname{Re}$ ，ある いは副交感神経性 $\operatorname{Re}$ 刺激薬をそれぞれ用いて 8 月齢 ラット耳下腺睡液のタンパク質成分の変化を検討した.

SDS, Native および IEF 像を Fig. 23 に示した。

どんな電気泳動法を用いて検討してみても, 用いた各 $\operatorname{Re}$ 刺激寱の種類に関係なく，分泌するタンバク質成分 には顕著な相違は出現しなかった。しかしながら，ラッ トが 8 および15月齢の中年齢になると，Fig. 24 に示す ように, 性別や刺激の種類に関係なく, 個体により老化 の兆候と思われる特徴的なタンパク質が諗められるよう

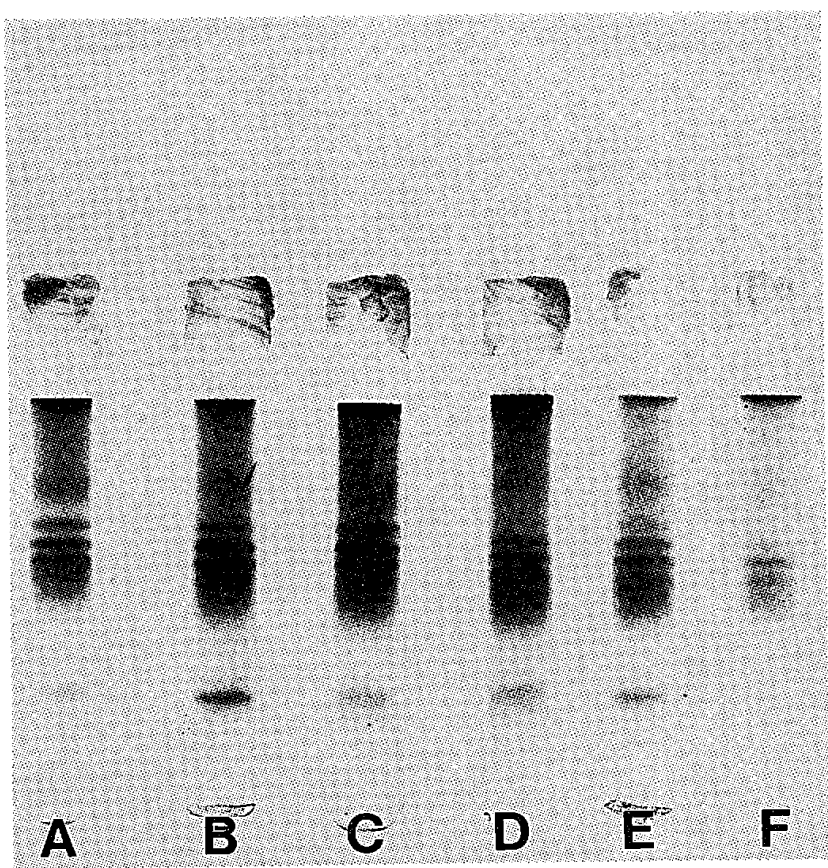

Fig. 19 Anionic polyacrylamide disc gel (7.5 $\%$ ) electrophoresis of male rat parotid saliva elicited by pilocarpine from $4(\mathrm{~A}), 5(\mathrm{~B}), 6(\mathrm{C}), 7(\mathrm{D}), 8(\mathrm{E})$, and $10(\mathrm{~F})$ weeks of age

Results obtained from both male and female rats in response to methoxamine were very similar and were therefore unshown. These results are also applicable to Figs. 20, 21, and 22 .

になった。しかしこれらの特徴は, SDS 電気泳動法で は譛められなかった。

B.アミラーゼアィソザイムパターンの変化

IEF（pH 3〜5） を用いてアミラーゼアィソザィム パターンを検討したのが，Fig. 25 である．本実験の Methox および Pilo 刺激菙液には pH 4.23，4.58， 4.71 および4.86の等電点をもつ 4 種のアイソザイムが検 出できた。乙れらのアイソザイムにも，タンパク質成分 の場合と同様に，加齢差および刺激差はほとんど認めら れなかった。

C.アミノ酸組成の変化

アミノ酸組成の分析は Methox 刺激權液の場合には, 各種のパラメータを測定後に残ったタンパク質が少量と なりアミノ酸組成の分析ができなかったので, 同じ交 感神経性 $\alpha_{1}-\operatorname{Re}$ 刺激薬である $\alpha-\mathrm{mNA}$ 刺激睡液と Pilo 刺激唾腹のタンパク質のアミノ酸組成を検索した

(Tables $3 \sim 5$ ). 耳下腺睡液タンパク質のアミノ酸 


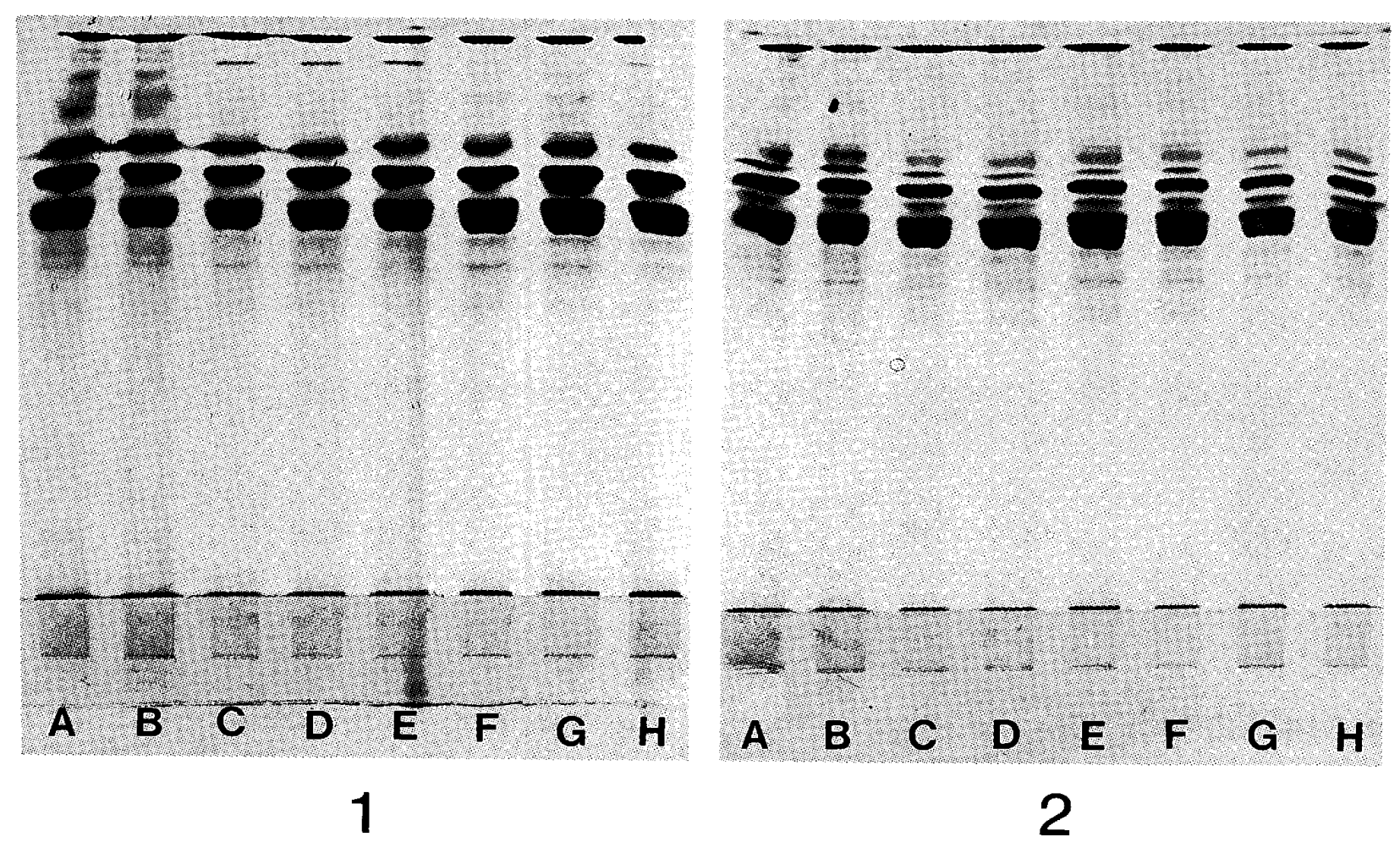

Fig. 20 The electrophoretograms stained with silver of parotid saliva of male(1) and female (2) rats in response to pilocarpine from $4(\mathrm{~A}), 5(\mathrm{~B}), 6(\mathrm{C}), 7(\mathrm{D})$, $8(\mathrm{E})$, and $10(\mathrm{~F})$ weeks, and $3.5(\mathrm{G})$ and $15(\mathrm{H})$ months of age using native gradient $(10-15)$ gels of the Phast system

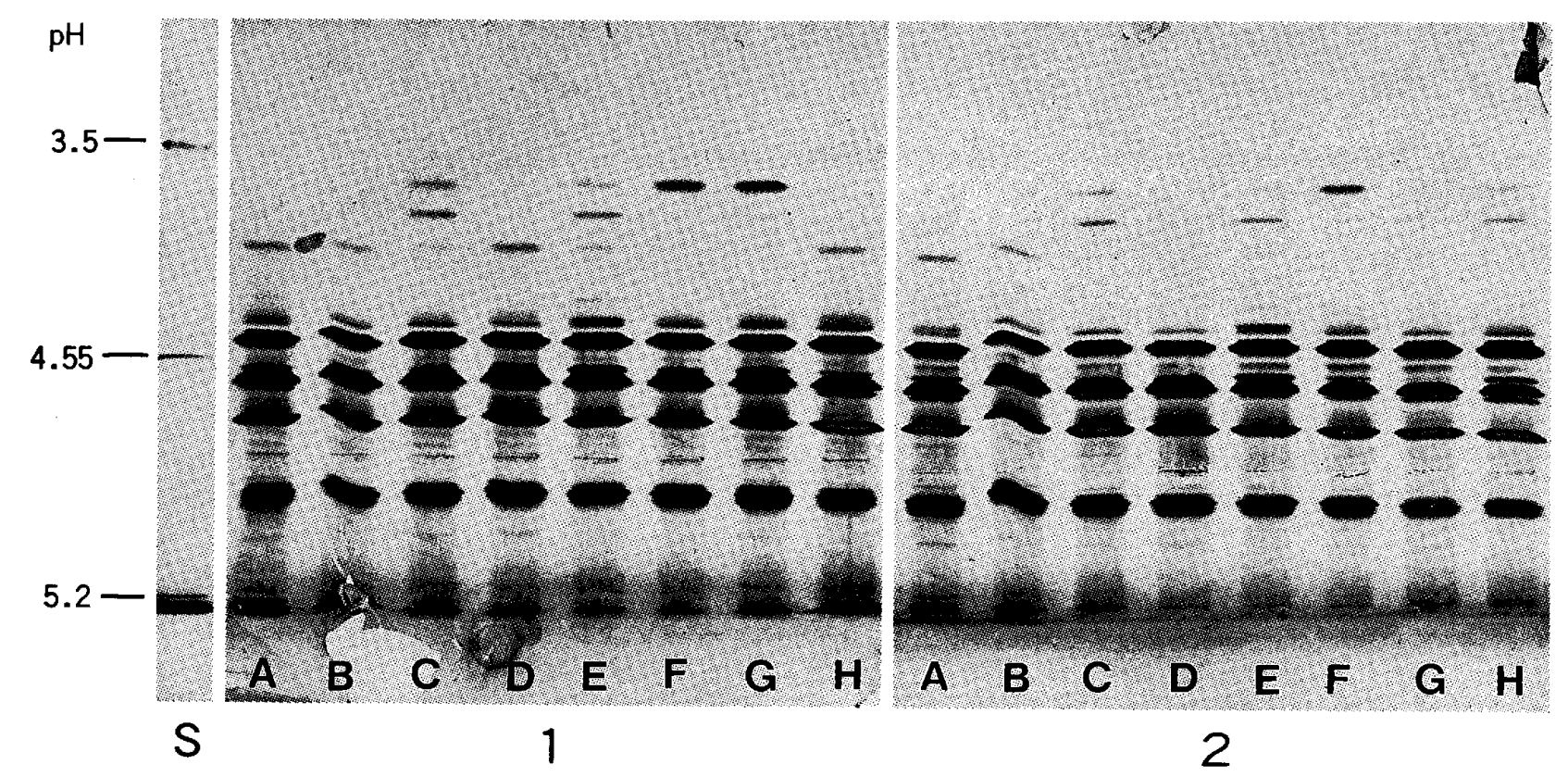

Fig. 21 The electrophoretograms stained with silver of male (1) and female (2) rat parotid saliva in response to pilocarpine from $4(\mathrm{~A}), 5(\mathrm{~B}), 6(\mathrm{C}), 7(\mathrm{D}), 8(\mathrm{E})$, and $10(\mathrm{~F})$ weeks, and $3.5(\mathrm{G})$ and $15(\mathrm{H})$ months of age using isoelectric focussing gradient ( $\mathrm{pH} 3-5$ ) gels of the Phast system $\mathrm{S}$; Standard substance. 
M.W.
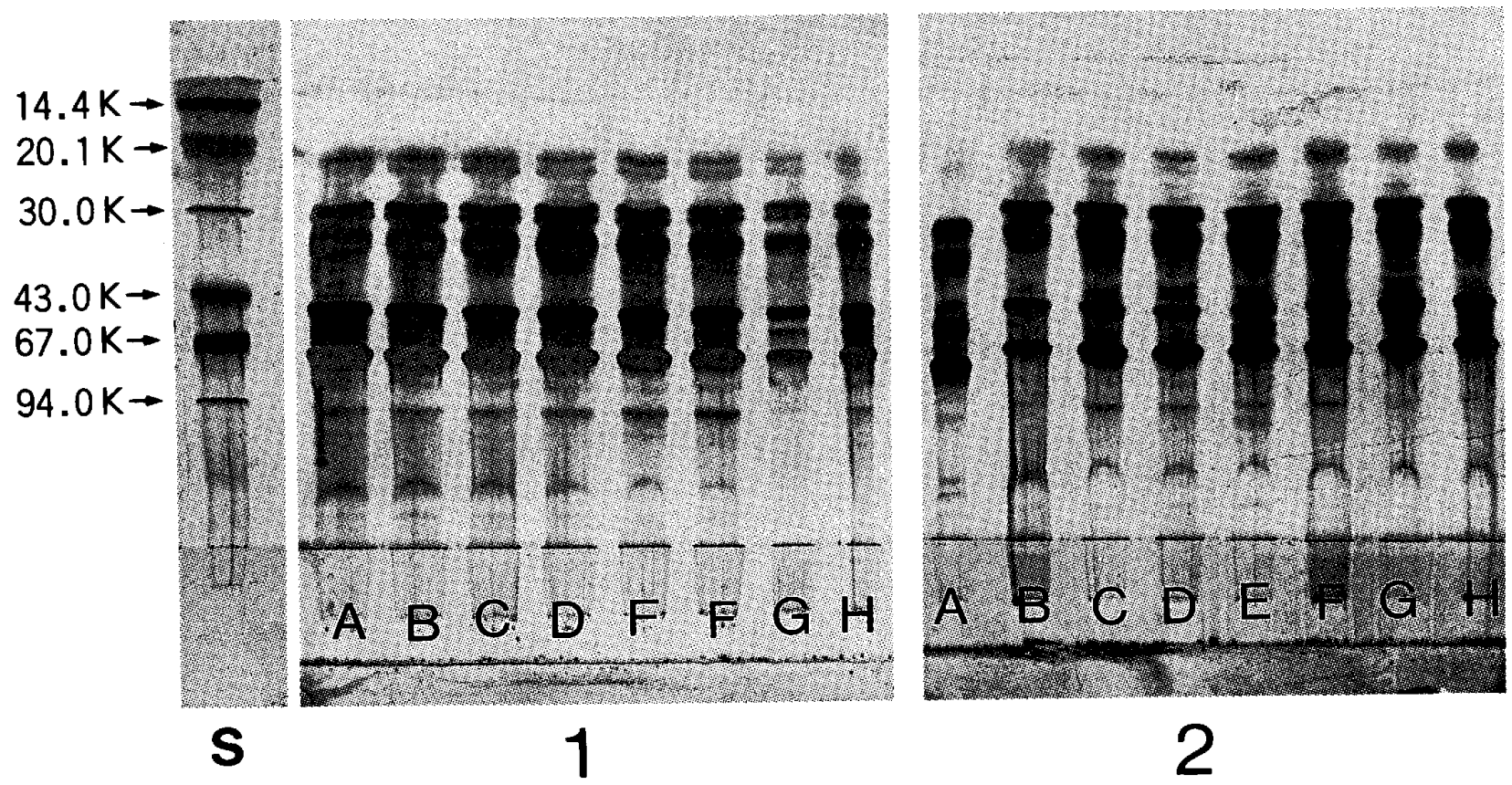

Fig. 22 The electrophoretograms stained with silver of male (1) and female (2) rat parotid saliva in response to pilocarpine from $4(\mathrm{~A}), 5(\mathrm{~B}), 6(\mathrm{C}), 7(\mathrm{D}), 8(\mathrm{E})$, and $10(\mathbf{F})$ weeks, and $3.5(\mathbf{G})$ and $15(\mathbf{H})$ months of age using SDS gradient $(10-15)$ gels of the Phast system $S$; Standard substance.

$\mathrm{pH}$

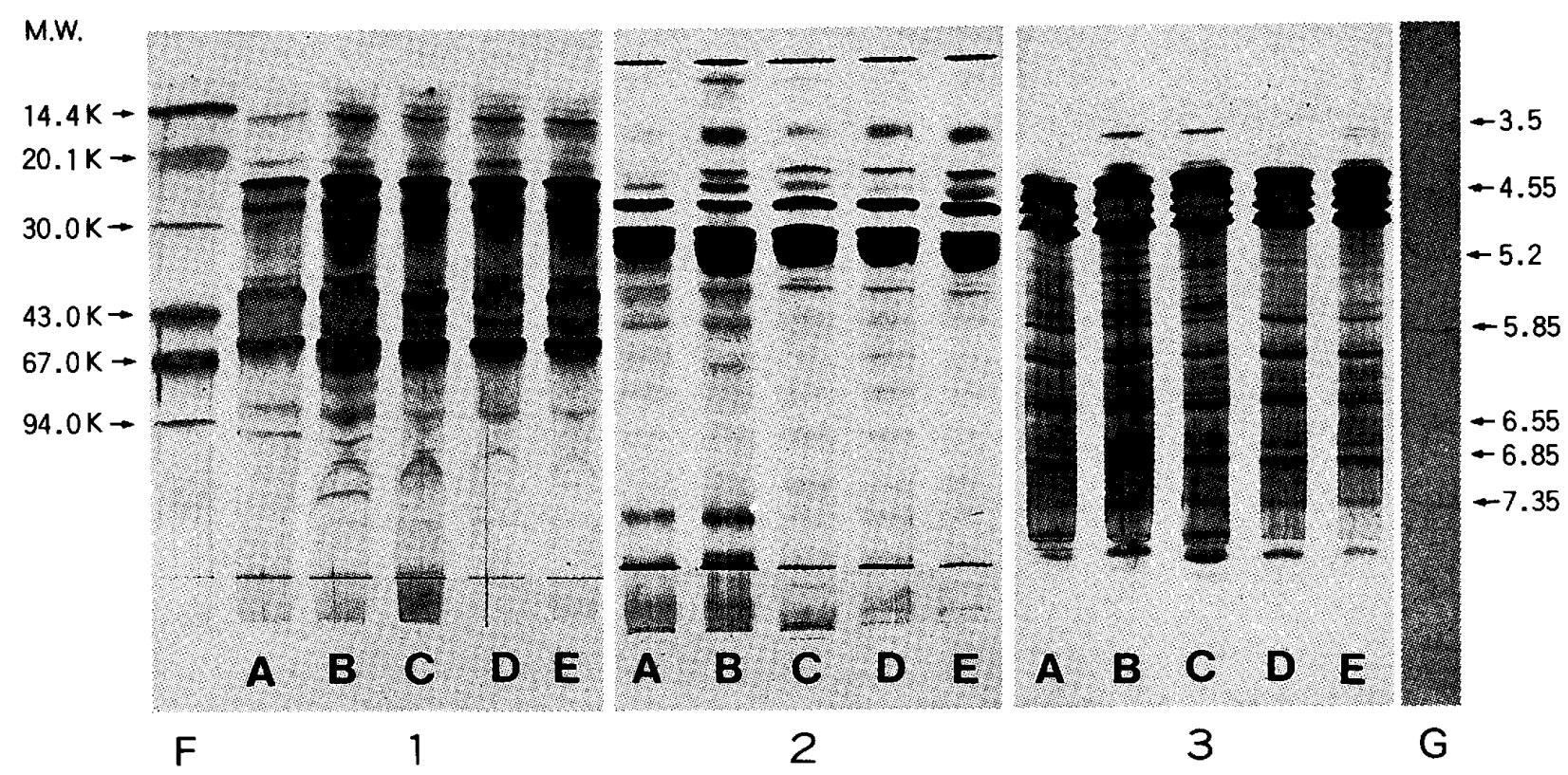

Fig. 23 The electrophoretograms stained with silver of male rat parotid saliva elicited by clonidine (A), methoxamine $(\mathbf{B})$, pilocarpine $(\mathbf{C})$, terbutaline $(\mathbf{D})$, and isoproterenol $(\mathrm{E})$ at 8 months of age using SDS gradient $(10-15)$ gels $(1)$, native gradient $(10-15)$ gels $(2)$, and isoelectric focussing gradient $(\mathrm{pH} 3-9)$ gels $(3)$ of the Phast system $F$ and G denote standard substances for SDS and IEF electrophoreses, respectively. 

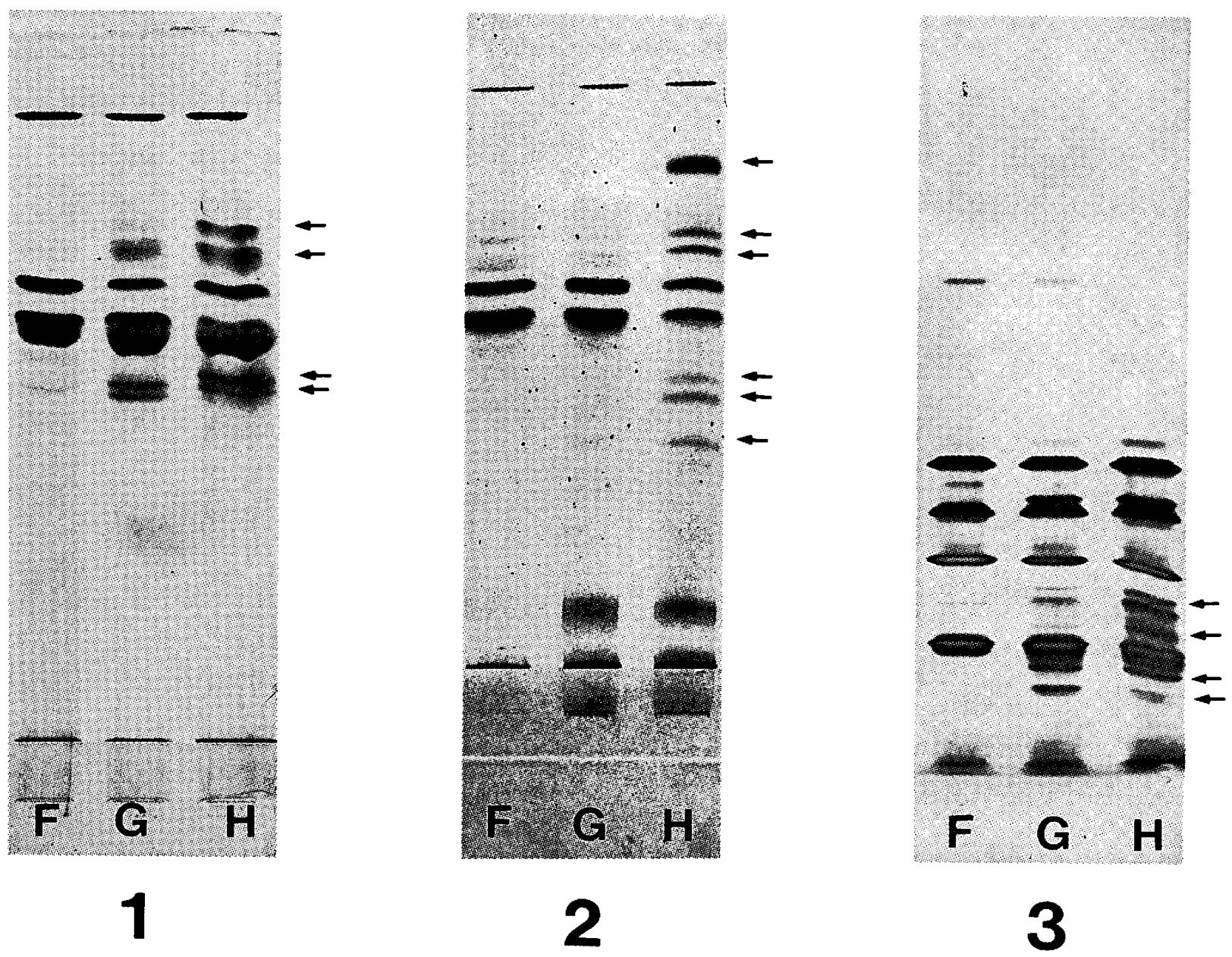

Fig. 24 The electrophoretograms stained with silver of male(1) and female (2) rat parotid saliva at $3.5(\mathrm{~F}), 8(\mathrm{G})$, and $15(\mathrm{H})$ months of age using native gradient (10-15) gel (1 and 2) and IEF (3), but not SDS gradient gel, electrophoreses in response to pilocarpine (1 and 3 ) and methoxamine (2)

Arrows denote unusual proteins demonstrated in middle aged rats ( $G$ and $H$ ).

残基の特徴は 1) アスパラギン酸，プロリン，グリシ ン, グルタミン酸, ロイシンおよびバリン残基が高濃度 であり，2）セリン, アラニン, スレオニン, リジン, アルギニン，イソロイシンおよびフェニルアラニン残 基が中程度を示し，3) メチオニン，チロシンおよびヒ スチジン残基が少量であった。また，シスチンは検出 できなかった，加齢差は，雄ラットの $\alpha-\mathrm{mNA}$ 刺激 (Table 3) ではグルタミン酸とプロリン残基に, Pilo 刺激（Table 6) ではプロリンとバリン残基にしか認め られなかった。

アミノ酸組成の性差は, Pilo 刺激の場合で検討 $(\mathrm{Ta}-$ ble 6) した。性差はアスパラギン酸, スレオニン, グ リシン, アラニン, バリンおよびチロシン残基に喼めら れた。

III . 義蒾床への付着タンパク質について
耳下腺唾液のタンパク質成分が義菊休に付着するかど うかを，2種類のレジン試験片を用いて検討した。タン パク質成分は刺激の種類で影響を受けないととがわかっ たので，8月歯ラットの Pilo 刺激唾液を用いた． $37^{\circ} \mathrm{C}$ で 1 週間の浸漬保存ではレジンの種類に関係なく試験片 に付着するタンパク質も極めて少量であった，また，表 面の鏡面忖上げ処理は，タンパク質付着に抑制的に働い た，付着したタンパク質成分を分析するためには，電気 泳動で銀染色できるタンパク質量を採取しなければな

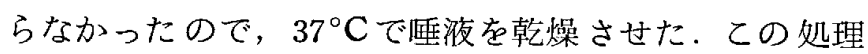
により，レジン床に付着するタンパク質が多くなった (Fig. 26).

この付着したタンパク質成分を検討したのが Fig. 27 である．付着するタンパク質成分は比較的移動度の大き い成分であるととがわかった。 


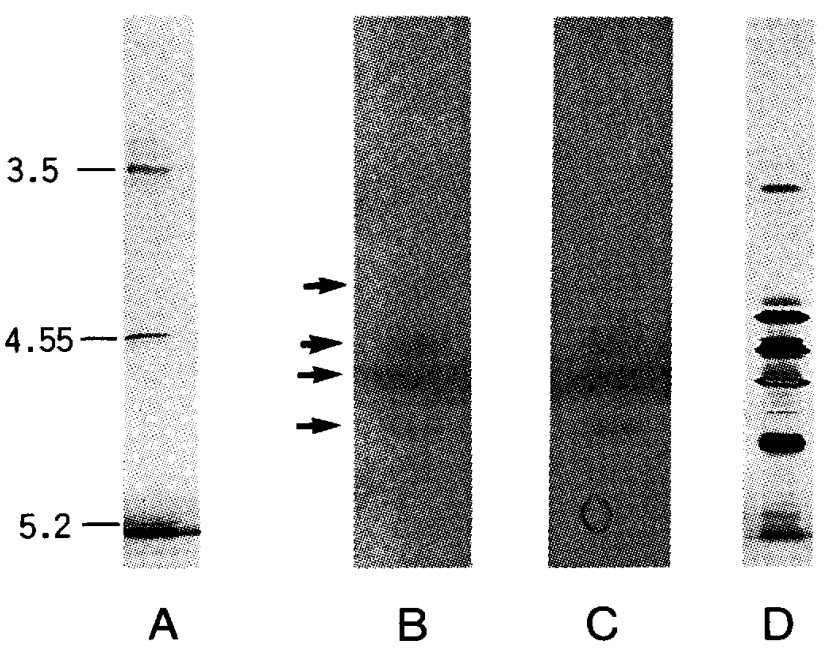

Fig. 25 The electrophoretograms of amylase isozyme patterns (arrows) of male rat parotid saliva at 8 months of age in response to pilocarpine (B) and methoxamine $(\mathrm{C})$ detected by the Blue Dextran method using the isoelectric focussing gradient $(\mathrm{pH} 3$ -5) gels of the Phast system. See the method in the text

A denotes standard substance and D electrophoretogram of proteins stained with silver of parotid salive of male rats at 8 months of age in response to pilocarpine as controls. No sex difference of amylase isozyme patterns was observed and was therefore unshown.
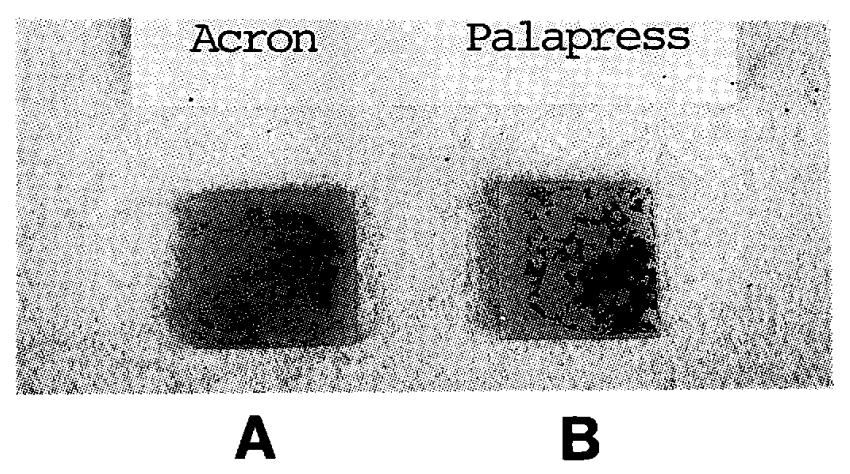

Fig. 26 A photograph of pilocarpine-stimulated parotid salivary proteins adhered to the mucosal surface of the two types of resin plates, incubated at $37^{\circ} \mathrm{C}$ for 1 week up to dry states, and stained with Wool Fast Blue

A, Acron ; B, Palapress.

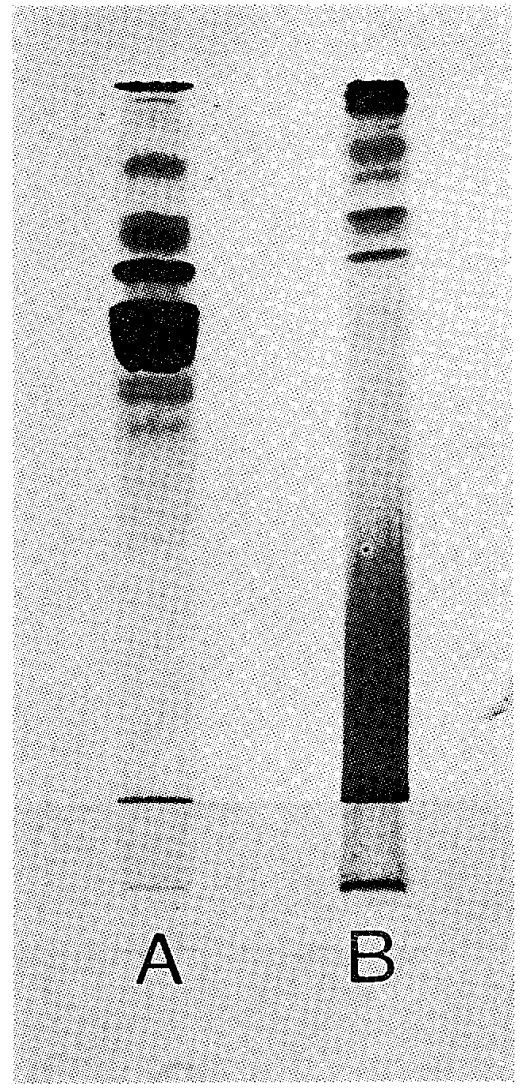

Fig. 27 An electrophoretogram stained with silver of pilocarpine-stimulated parotid salivary proteins of male rats at 8 months of age adhered selectively to the resin plate using native gradjent $(10-15)$ gels of the Phast system

A denotes pilocarpine-stimulated saliva of male rats at 8 months of age as controls and $B$ denotes proteins adhered selectively to resin plate (Acron).

IV 、自律神経系機能の加䛧令的変化について

自律神経性 $\operatorname{Re}$ 遮断薬と Methox あるいは Pilo とを 組み合わせて, 哽液分泌の有無から自律神経系の機能を 検討した（Table 7)。Methox 刺激の場合にはフェノ オキシベンザミン，フェントラミンおよびジヒドロエル ゴタミンにより，Pilo 刺激ではアトロピンにより，全 被験年齢ラットの倕液分泌が完全に抑制された。このこ とから，交感神経性 $\alpha_{1}-\operatorname{Re}$ および副交感神経性 $\operatorname{Re}$ の分泌機能は 4 週齡ですでに完成し，15月齢に至るまで 不変であることが示唆された。 
Table 3 The effects of $\alpha$-methylnoradrenaline on amino acid composition of male rat parotid saliva from $4 \sim 10$ weeks to 3.5 months of age

\begin{tabular}{l|r|r|r|r|r|r|r|c}
\hline \hline Age (week and month) & \multicolumn{1}{|c|}{4} & \multicolumn{1}{|c|}{5} & \multicolumn{1}{|c|}{6} & \multicolumn{1}{|c|}{7} & \multicolumn{1}{|c|}{8} & \multicolumn{1}{c}{10} & $3.5 \mathrm{M}$ & F.analysis \\
\hline Lysine & \multicolumn{1}{|c|}{$4.0^{*}$} & 4.2 & 4.1 & 4.3 & 4.2 & 4.1 & 4.5 & N.S. \\
Histidine & 2.2 & 2.3 & 2.3 & 2.3 & 2.2 & 2.3 & 2.9 & N.S. \\
Arginine & 4.3 & 4.0 & 4.6 & 4.3 & 4.6 & 4.3 & 4.4 & N.S. \\
Aspartic acid & 12.6 & 12.8 & 12.7 & 13.2 & 13.2 & 12.5 & 13.0 & N.S. \\
Threonine & 4.3 & 4.5 & 4.5 & 4.5 & 4.8 & 4.4 & 4.8 & N.S. \\
Serine & 6.5 & 6.7 & 6.7 & 6.6 & 6.8 & 6.6 & 6.7 & N.S. \\
Glutamic acid & 10.1 & 11.3 & 9.4 & 9.9 & 9.2 & 9.2 & 8.9 & P $<0.05$ \\
Proline & 12.7 & 12.8 & 11.2 & 11.0 & 9.9 & 11.8 & 11.9 & P $<0.01$ \\
Glycine & 10.6 & 10.5 & 10.7 & 10.0 & 9.7 & 10.5 & 9.2 & N.S. \\
Alanine & 6.2 & 6.0 & 5.9 & 6.1 & 6.2 & 6.4 & 6.2 & N.S. \\
Valine & 7.9 & 7.2 & 8.1 & 8.3 & 7.9 & 8.2 & 7.0 & N.S. \\
Methionine & 0.3 & 0.3 & 0.5 & 0.4 & 0.4 & 0.5 & 0.7 & N.S. \\
Isoleucine & 3.6 & 3.5 & 3.6 & 3.9 & 4.2 & 3.5 & 3.4 & N.S. \\
Leucine & 9.6 & 9.1 & 9.7 & 9.6 & 10.6 & 9.9 & 10.0 & N.S. \\
Tyrosine & 1.3 & 1.1 & 2.1 & 1.6 & 2.1 & 1.8 & 2.3 & N.S. \\
Phenylalanine & 3.8 & 3.7 & 3.9 & 4.0 & 4.0 & 4.0 & 4.1 & N.S. \\
\hline
\end{tabular}

*, Total amino acids are expressed as 100 residues.

These are also applicable to Tables 4 and 5 .

Table 4 The effects of pilocarpine on amino acid composition of male rat parotid saliva from $4 \sim 10$ weeks to 3.5 months of age

\begin{tabular}{l|r|r|r|r|r|r|r}
\hline \hline Age (week and month) & \multicolumn{1}{|c|}{4} & \multicolumn{1}{|c|}{5} & \multicolumn{1}{|c|}{6} & \multicolumn{1}{c|}{7} & \multicolumn{1}{c|}{8} & \multicolumn{1}{|c}{10} & $3.5 \mathbf{M}$ \\
\hline Lysine & 4.0 & 3.9 & 3.5 & 4.1 & 3.9 & 4.3 & 3.9 \\
Histidine & 2.2 & 2.2 & 2.1 & 2.1 & 2.1 & 2.1 & 2.3 \\
Arginine & 3.6 & 4.3 & 4.0 & 4.2 & 3.8 & 4.0 & 4.6 \\
Aspartic acid & 12.3 & 12.3 & 12.1 & 12.5 & 12.8 & 13.0 & 12.8 \\
Threonine & 4.2 & 4.3 & 3.9 & 4.0 & 4.2 & 3.9 & 5.8 \\
Serine & 6.8 & 6.3 & 6.6 & 6.4 & 6.4 & 5.9 & 5.5 \\
Glutamic acid & 9.4 & 10.1 & 10.0 & 9.4 & 9.3 & 9.2 & 10.2 \\
Proline & 13.9 & 13.5 & 15.9 & 13.4 & 12.2 & 14.0 & 12.4 \\
Glycine & 9.8 & 10.2 & 9.5 & 9.2 & 9.6 & 8.8 & 10.5 \\
Alanine & 6.0 & 5.8 & 6.0 & 6.2 & 6.7 & 6.4 & 5.2 \\
Valine & 6.7 & 6.8 & 6.6 & 7.0 & 7.7 & 7.2 & 7.1 \\
Methionine & 0.8 & 0.7 & 0.6 & 0.7 & 0.6 & 0.8 & 0.5 \\
Isoleucine & 4.4 & 4.2 & 4.3 & 4.3 & 4.6 & 4.2 & 4.2 \\
Leucine & 10.7 & 10.2 & 10.1 & 10.9 & 11.0 & 10.9 & 9.5 \\
Tyrosine & 1.4 & 1.4 & 1.1 & 1.6 & 1.1 & 1.4 & 1.8 \\
Phenylalanine & 3.8 & 3.8 & 3.7 & 4.0 & 4.0 & 3.9 & 3.7 \\
\hline
\end{tabular}


Table 5 The effects of pilocarpine on amino acid composition of female rat parotid saliva from 5 to 10 weeks of age

\begin{tabular}{l|r|r|r|r|r}
\hline $\begin{array}{l}\text { Age (week and } \\
\text { month) }\end{array}$ & \multicolumn{1}{|c|}{5} & \multicolumn{1}{|c|}{6} & \multicolumn{1}{c|}{7} & \multicolumn{1}{c}{8} & \multicolumn{1}{c}{10} \\
\hline Lysine & 3.8 & 4.0 & 3.9 & 4.3 & 3.9 \\
Histidine & 1.6 & 1.8 & 1.7 & 2.0 & 1.9 \\
Arginine & 3.9 & 3.8 & 4.0 & 4.2 & 4.2 \\
Aspartic acid & 11.3 & 10.3 & 12.2 & 11.1 & 11.9 \\
Threonine & 5.5 & 5.7 & 5.2 & 4.9 & 4.9 \\
Serine & 6.7 & 10.3 & 6.6 & 7.2 & 7.7 \\
Glutamic acid & 11.0 & 11.3 & 9.9 & 11.1 & 8.9 \\
Proline & 12.0 & 12.8 & 11.0 & 10.6 & 12.1 \\
Glycine & 11.0 & 9.5 & 10.3 & 10.1 & 9.8 \\
Alanine & 4.5 & 5.0 & 4.6 & 4.9 & 4.2 \\
Valine & 8.0 & 7.3 & 8.3 & 8.3 & 8.2 \\
Methionine & 0.8 & 0.8 & 1.1 & 1.1 & 0.8 \\
Isoleucine & 4.1 & 3.7 & 4.4 & 4.4 & 4.1 \\
Leucine & 10.6 & 9.3 & 11.4 & 10.2 & 11.9 \\
Tyrosine & 1.6 & 1.4 & 2.0 & 2.0 & 1.9 \\
Phenylalanine & 3.6 & 3.0 & 3.4 & 3.6 & 3.6 \\
\hline
\end{tabular}

Table 6 Two way analyses of variances of age and sex effects on the developmental changes of amino acid concentration in parotid saliva of rats in response to pilocarpine

\begin{tabular}{l|c|c}
\hline \multicolumn{1}{c|}{ Factor } & A & B \\
\hline Lysine & N.S. & N.S. \\
Histidine & N.S. & N.S. \\
Arginine & N.S. & N.S. \\
Aspartic acid & N.S. & P $<0.01$ \\
Threonine & N.S. & P $<0.01$ \\
Serine & N.S. & N.S. \\
Glutamic acid & N.S. & N.S. \\
Proline & P $<0.05$ & N.S. \\
Glycine & N.S. & P $<0.01$ \\
Alanine & N.S. & P $<0.01$ \\
Valine & P $<0.05$ & P $<0.01$ \\
Methionine & N.S. & N.S. \\
Isoleucine & N.S. & N.S. \\
Leucine & N.S. & N.S. \\
Tyrosine & N.S. & P $<0.01$ \\
Phenylalanine & N.S. & N.S. \\
\hline
\end{tabular}

Factor A and B denote age and sex differences respectively by ANOVA

Table 7 The effects of different autonomic blockers in combination with methoxamine and pilocarpine on the salivation of the parotid glands of male rats from 4 weeks to 15 months of age

\begin{tabular}{c|c|c|c|c|c|c}
\hline \hline $\begin{array}{c}\text { Stimulants } \\
+ \\
\text { Blockers }\end{array}$ & \multicolumn{3}{|c|}{ Methoxamine } & \multicolumn{3}{c}{ Pilocarpine } \\
\cline { 2 - 7 } $\begin{array}{c}\text { Phentolamine } \\
\text { Phenoxybenzamine } \\
\text { Dihydroergotamine }\end{array}$ & Atropine & Propranolol & Phentolamine & Atropine & Propranolol \\
\hline $\begin{array}{c}\text { Age (week and } \\
\text { month) }\end{array}$ & & & & & & \\
4 & $-*$ & $+* *$ & + & + & - & + \\
5 & - & + & + & + & - & + \\
6 & - & + & + & + & - & + \\
7 & - & + & + & + & - & + \\
8 & - & + & + & + & - & + \\
10 & - & + & + & + & - & + \\
$3.5 \mathrm{M}$ & - & + & + & + & - & + \\
$15 \mathrm{M}$ & - & + & + & + & - & + \\
\hline
\end{tabular}

*, Denotes no salivation;**, Denotes salivation occurred 


\section{考}

察

老人人口の増加に伴う義雨装着患者の増加が，将来補 綴学分野の重要な課題になることは必至である。しかし ながら，老略化に伴う口腔組織の変化に関する研究は近 年になってようやく積極的に始まったばかりである52， ${ }^{53)}$. 咬合や咀嚼機能が耳下腺の機能に関係するととは, 多数の研究者 ${ }^{38-42 '}$ 年報告している．てれらのととか ら，本実験では，4 週齢から15月齢に至るラット耳下腺 の交感神経性 $\alpha_{1}$ - 之副交感神経性 $\operatorname{Re} の$ 分泌機能を年 畔令，刺激の種類および性別から検討した。また義蒾床一 の付着タンパク質の分析も行った．以下の 3 項目につい て考察する。

\section{A. 腺湿重量と分泌喠液量について}

ラット耳下腺の腺湿重量は, 雌雄ともに，3 週齢では 非常に小さく $(132.9 \pm 3.1 \mathrm{mg}, \mathrm{n}=12)$ ，どんな刺激薬 を用いても重液採取はできなかった。このととは，ラッ 卜耳下腺は 2,3 週齢になると急激に増殖し, 分泌機能 だけでなく，副交感および交感神経支配が完了するとい う報告 $\left.{ }^{2}, 3,12-15\right)$ と一致しなかった。また 4 週齢になっ たばかりの雌ラットの場合には，Pilo 刺激耳下腺睡液 は採取できなかった。 4 週齢になって 4 日後に初めて実 験群の $\% 3$ のラットの棰液採取が可能となった．Methox 刺激の場合には Pilo 刺激と異なって 4 週梌になったば かりで唾液採取ができた。どういう理由で 3 週㱓で，あ るいは, Pilo 刺激の雌の場合には 4 週路の初めでも， 睡液が採取できなかったかはわからないが，耳下腺睡液 のタンパク質濃度が極端に高くなり，粘度が上昇したて とが原因かも知れない．先人達の報告 $2,3,12-15)$ のよ に，3 週齢では分泌機能をすでに備えているが，極く少 量の唾液しか分泌しないために，本採取法では喠液が採 取できなかったとも思われる．雌ラットのPilo 刺激の 耳下腺の分泌厜液量のみが, 腺湿重量と順相関しなかっ た結果も，同様のととが原因であったと思われる．4〜 8 週秢にかけて腺湿重量が急上昇し, それ以後漸增し た。さらに，15月跲で減少した。このことは，ヒ卜顎下 腺の重量は中高年齢化とともに減少するという報告 ${ }^{54}$ と一致する．体重が 5 週齢から統計的に有意な性差を示 したのに対し，腺湿重量は 5 週柃まで性差を示さなかっ たが， 5 週齢以後の腺湿重量の増加には明瞭な性差が認

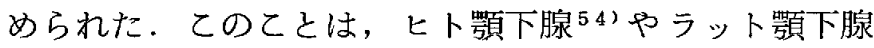
55,56) に認められた性差に関する報告と同傾向を示し た。

分泌哽液量には, Methox 刺激を行った雌雄ラット
とも加齢差は認められなかった，このことは, Baum $\left(1981 \mathrm{a}^{37} ， 1981 \mathrm{~b}^{52}\right)$ のヒト耳下腺に関する報告と一 致する. 分泌棰液量の性差については, Methox 刺激 の場合には性差は認められなかったが，Pilo 刺激には 加齢差だけでなく性差も認められた（Table 2).との ことは, Dawes ら (1965) ${ }^{57)}$ の報告と一致する。ま た, 本実験の分泌厔液量は, 刺激の種類, 年齢および性 別を考えなかった場合には腺湿重量に有意な順相関を示 した。しかし両刺激の雌の場合には, 両者間に有意な相 関は認められなかった。

ヒトの顎下腺 ${ }^{8}$ ) および耳下腺59 ${ }^{5}$ の分泌唾液量は腺湿 重量と順相関するという報告がみられる。また，ラット 顎下腺でも Pilo 刺激の場合には, 雌雄ともに, 分泌㗆 液量は腺湿重量に順相関したが Methox 刺激の場合に は, 雌雄ラットはともに, 顆粒管の発育し始める 6 週歯 より分泌哽液量と腺湿重量とは順相関しなくなったの で, Abe ら (1987 ${ }^{56}$ ) は交感神経性 $\alpha_{1}-\operatorname{Re}$ が強く支

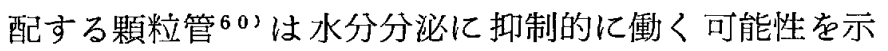
唆している.乙れらのことから，特殊な場合を除くと， 分泌唾液量は一般に腺湿重量に順相関すると考えた方が い上うに思える、したがって，ラットでは腺湿重量と 体重が順相関している幼若時では分泌唾液量は体重に順 相関するととになる。しかし Dawes ら（1978）59'がヒ 卜耳下腺唾液の分泌量は体重とか，身長などに順相関し ないと述べているてとから, 成熟期以後の分泌量には腺 湿重量以外の因子も大きく関与するてとになる。

囯液腺からの分泌唾淮量は主として副交感神経性 $\mathrm{Re}$ および交感神経性 $\alpha$ - Re により調節されている17'。 しかしながら，ラット耳下腺では副交感神経性 Re およ び交感神経性 $\beta-\operatorname{Re}$ の数や機能 ${ }^{13,26,34)}$ は加齢で変化 しないが， $\alpha-\operatorname{Re}$ の生理機能 ${ }^{2-34)}$ は老齢化で減退す ると報告されている.しかし, 本実験で用いた各週齢の ラット耳下腺の副交感神経性, 交感神経性 $\alpha_{1}$ 一およ び $\beta-\operatorname{Re} の$ 分泌機能は完全であったてとが示されてい る (Table 7). しかし, 老踰化に伴い四液腺は分泌, 合成機能 $27,28,30,31)$ げげなく, 組織学的 24,25$)$ 亿も 脂肪化や結合織化が起とり, 腺湿重量も減少するから 521 分泌睡液量も老跘化で咸少するととが予想できるし， 多くの研究者 ${ }^{61}$ もこれと類似の報告をしている.しか し本実験に用いた15月齢ラットは老秢というより中年齢 という表現が適当であるから，分泌㗆液量に加跲に伴う 有意な減少は認められなかった。しかしヒトの場合でも 同様な報告 37 ，52'がみられる。

Sreebny ら $(1971)^{62)}$ および Hand ら $(1981)^{38) な ~}$ 
どは，栄養価が十分でも液体飼料をラットに与えると， 耳下腺の腺湿重量が顕著に減少するととを報告してい

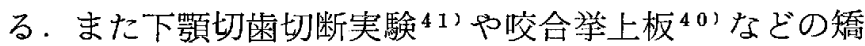
正装置を装着して咀嚼機能を減少させても，耳下腺は㮃 縮すると報告されている。また逆に，栄養価の低い容積 の大きい飼料でラットを飼育すると, 耳下腺の腺湿重量 が大きくなることが報告 ${ }^{39}$ さされている．乙れらのこと から，耳下腺の大きさには，加齢と同椂に咀嚼や咬合が 大きく関与していることになるので補緅物製作の優劣は 分泌㗆液量に重大な影響を与えるととになると思われ る. 逆に，この種の研究が発度するととにより，作製さ れた補綴物が，顎口腔系にどのように調和しているかを 判定することも可能となるのではないかと思われる。

B．タンパク質濃度，アミラーゼ活性および無機質濃 度について

タンパク質濃度および画表示の分泌タンパク質量は， Pilo 刺激の雌を除いた場合には, 加㱓に伴い有意に増 加した。また，両刺激とも，一部を除くと，顕著な性差 を出現した。一般に耳下腺唾液のタンパク質濃度, 分泌 タンパク質量およびアミラーゼ活性の程度は，交感神経 性 $\beta-\operatorname{Re}, \alpha-\operatorname{Re}$ および副交感神経性 $\operatorname{Re}$ 刺激の順に 小さくなる16,17,63,64)。しがしながら，Piloは，特

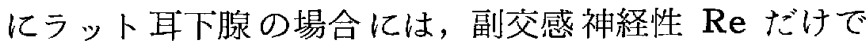
なく, 交感神経性の上頸神経節の節後線維も刺激するこ とが明らかにされている65)ので, 交感神経性 $\alpha_{1}-\mathrm{Re}$ を刺激する Methox 刺激で認められた Pilo 刺激の場 合より低いタンパク質濃度，分泌タンパク質量扎よびア ミラーゼ活性は理解できる.乙れらのことは, 先人達 $16,17,63 \sim 65)$ の報告とも一致した。一般に，タンパク質 濃度および分泌タンパク質量は各種の奏験条件により変 動することが知られている16,17)が，特に唾液の分泌速 度に大きな影響を受ける20４7)。本実験でもタンパク質 濃度は分泌速度と，それが速い場合と遅い場合とで，そ れぞれ順および逆相関するととがわかった（Fig．7）。 これらの相関は刺激の種類, 年粭および性別に関係し ないととが，幼若扔よび成熟ラットを用いた钼下腺 ${ }^{19 ，}$ $55,56)$ や耳下腺唾液 ${ }^{19)}$ のタンパク翼の分泌関する報 告からも理解できる. 本実験ではタンパク質濃度と分泌 速度との相関関係に刺激差が認められたような結果を示 している（Fig，7）が，てれは，たまたま本実験に用 いた 2 種類の刺激が偶然に遅い分泌速度と速い分泌速度 を示したにすぎなと考えられる。したがって，Pilo 刺激の雌ラットの場合以外のタンパク質濃度や分泌タン パク質量は, 年歯, 性別および刺激の種類に関係なく,
成熟ラットと全く同じ機構により決定されていることが わかる。

アミラーゼ活性では, タンパク質濃度と同じく, Pilo 刺激の場合に性差が認められた。このことは，Bellavia ら (1981 $\left.{ }^{35}\right)$ の報告と一致した。しかし, 両刺激とも加 齢茬は出現しなかった（Table 2)．このこともヒト耳 下腺での観察 ${ }^{2}$ ) と一致した。特に耳下腺唾液のアミラ 一ゼ活性は，タンパク質濃度や分必タンパク質量と同じ く， $\beta-\operatorname{Re}, \mathrm{cAMP}$ およびプロティンキナーゼに依存 するととは周知のととである12,13,34．したがって， ラット耳下腺唾液のアミラーゼ活性はタンパク質濃度と 極めて類似の挙動を示すととになる.すなわち, 老齢化 でタンパク質濃度が低下するとアミラーゼ活性も低下す る54,66)。 また，アミラーゼ活性と腺湿重量およびアミ ラーゼ活性と睡液の分泌速度との相関関係は, タンパク 質濃度とこれらのパラメータとの相関関係と極めて類似 していた，すなわち，分必速度が遅い場合と速い場合と でアミラーゼ活性はその速度と逆あるいは順相関した。 このことは，アミラーゼ活性は唾液の分泌速度に大きな 影響を受けるという多くの報告 ${ }^{67}$ と一致する。本実験 でも，アミラーゼ活性はタンパク質濃度と極めて高い相 関係数をもつ有意な順相関を示した（Fig１2）。乙れら のことから，アミラーゼ活性も年粭, 性別および刺激の 種類に関係なく，成熟ラットの場合と類似の結果を示す ことがわかった。

$\mathrm{Ca}$ とタンパク質あるいはアミラーゼとは，特に耳下 腺の場合には，平衡関係を保って分泌することが報告 68-70)されている. しかし，タンパク質やアミラーゼ分 泌には交感神経性 $\alpha_{1}$ 一および副交感神経性 $\operatorname{Re} は$ はと んど重要な役割を演じていないととが報告 ${ }^{68)}$ されてい る. 本実験で用いた Methox および $\alpha$ - mNA（未発 表データ) はどちらも交感神経性 $\alpha_{1}-\operatorname{Re}$ 刺激薬であ り，また Pilo は交感神経性 $\beta$ - Re 刺激作用を一部分 しかもたない65”から，Ca 濃度とタンパク質濃度にお ける本実験の相関関係は先の報告68-70) と異なる結果を 示している.

しかしながら，交感神経性 $\alpha_{1}-\operatorname{Re}$ 刺激唾液のアミ ラーゼ活性と $\mathrm{Ca}$ 濃度は Methox と $\alpha$ - mNA（未発 表データ) のどちらの刺激の場合も，また踓雄ラットと も，有意な順相関を示した。しかし Pilo 刺激の場合の 雌雄ラットの場合には雨者間に順相関は存在しなかっ た. 本実験の Methox および Pilo 刺激の Ca 濃度に は，加齢に伴う特徴的な推移は観察できなかったし， Methox 刺激の場合には，性差も認められなかった。こ 
のととは，Methox を用いたラット顎下腺哽液での報告

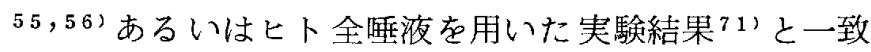
しなかったが，Pilo 刺激の場合には，ラット顎下腺で

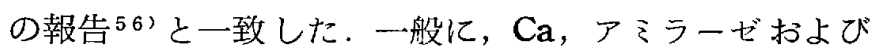
タンパク質は，既述のように，同じ機構で分泌するか ら，アミラーゼ活性やタンパク質濃度の高い Pilo 刺激 唾液の Ca 濃度の方が Methox 刺激のもの上り有意に 高い值を示したことは理解できる．本実験では，全 $\mathrm{Ca}$ 量を測定したが，七卜厓没全 $\mathrm{Ca}$ 量と遊離の $\mathrm{Ca}$ オン濃度とは順相関することが報告 ${ }^{22}$ されれている。ま た，結合型の Ca 濃度はタンパク質濃度に順相関するこ とも報告 ${ }^{20)}$ されているので，本実験で測定した全 $\mathrm{Ca}$ 量の加齢差，性差抢よび刺激差に関する実験結果は遊離 あるいは結合型 $\mathrm{Ca}$ 濃度にも適応するととができる.

Kおよび Pi 濃度には加齢差は認められなかった．特 にPi 濃度の場合には，ヒ卜全承液に関する報告 ${ }^{71)}$ 一致した。しかし, Pilo 刺激のラット顎下脉西液の $\mathrm{K}$ および Pi 濃度は加齢差を示すという報告55,56) とは一 致しなかった．Pi 濃度は Methox 刺激睡液に性差が認 められた。乙れらの本実験結果は，ヒ卜全唾液71拉よ びラット顎下腺睡夜での報告 55,56$)$ と一致した。しかし ヒ卜全乗液の $\mathrm{Pi}$ 濃度は，50歳以上になると性差を示す が， 5 〜歳児では性差を示さなかったと報告711され ている. 本実験での $\mathrm{K}$ 抢よび Pi 濃度は，年柃，性別お よび刺激の種類に関係なく, 唾液の分泌速度に逆相関し た。このてとは, 多くの先人達の報告 $18,55,56)$ と一致 する。したがって，Pi および K 濃度は分泌速度と強く 関係していることになるので, 両パラメータに認められ た性差は腺湿重量あるいは腺湿重量に相関する分泌厘液 量に認められる性差を反映した結果である。だから，幼 若時に性差が認められなかった結果は肯定できる。しか し重液腺でのKの放出には, 副交感神経性, 交感神経性 $\alpha_{1}$ 一およびペプチド性 $\operatorname{Re}$ がそれぞれ関与しているこ とはよく知られている73)。

幼若および成熟ラット顎下腺の交感神経性 $\alpha_{1}$ 一およ び $\alpha_{2}$ - Re の刺激は高濃度の K 在喠液中に分泌するが， 成熟ラット耳下腺唾液中には高濃度の $\mathrm{K}$ を分泌しないと とが報告 $21-23,55,56)$ されている，本実験でも， $\mathrm{Me}^{-}$ thox 刺激唾液のK濃度は, 雌雄とも, Pilo 刺激のもの より有意に高い值を示していたが，幼若抢よび成熟ラッ 卜顎下腺唾液21-23,55,56) 亿認められたような高值を示 すととはなかった。このととは，本実験に用いた各年齢 のラット耳下腺では，Na， Cl およびKが Cotransport 系74)を介して, Bosolaterally 亿放出されていると考
えるととができる。

C．整液のタンパク質成分，アミラーゼアイソザィム パターンおよびアミノ酸組成について

幼若 ${ }^{5}$ ) および成熟の雌雄ラット頸下腺あるいは犬や 猫の顎下腺および耳下腺 ${ }^{75}$ )などは, 刺激の種類や年齢 により，質的に異なるタンパク質成分や糖鎖の異なるグ リコプロティンを分必するてとが報告されている．特に ラット領下腺では, 交感神経性 $\alpha_{1}$ 一および $\alpha_{2}-\operatorname{Re}$ 刺 激の場合17,21-23,55) には，交感神経性 $\beta$ 一および $\beta_{2}$ 一 $\operatorname{Re}$ あるいは副交感神経性 $\operatorname{Re}$ 刺激の場合之異なる夕 ンパク質成分が分在する。しかし，成熟ラット耳下腺で は刺激の種類により，質的に異なるタンパク質成分が分 泌するという報告はみられない，本実験で用いた $\mathrm{Me}$ thox および Pilo 刺激の場合には, 海液のタンパク質 成分は加秢差，性差および刺激差を出現しなかった。ま た 8 月齢ラットを用いた本実験結果（Fig．23）では， 交感神経性 $\beta-, \beta_{2}$ 一， $\alpha_{1}$ 一抢よび $\alpha_{2}-\operatorname{Re}$ ，あるい は副交感神経性 $\operatorname{Re}$ 刺激整液のタンパク質成分は, 各種 の電気泳動法で検討してみても極めて類似の電気泳動像 が得られた。乙れらの所見は, Dawes $\left(1981^{76}\right), 1984$ 77)）のヒト耳下腺での報告やウサギの膵液酵素の分泌 にみられる Parallelism ${ }^{78}$ を肯定する。しかし，膡液 䤃素の場合には，Parallelism を示さないという報告 79) あある.また，ヒト耳下腺の場合には個体差がみら れるという報告 ${ }^{76}$ もある。本実験でも IEF の等電点 の低い微量成分の電気泳動像に性別, 年齢および刺激の 種類に関係なく個体差が出現した。また雌雄ラットが 8 および15月齢になると，タンパク質成分に顕著な相違が 出現するようになった（Fig．24）。乙れらのタンパク質 成分が老軨化の診断や兆候になりうるかどうか柱不明で あり，今後の研究が待たれる，Kim および Kim らの 一連の報告 27-311 亿よると, 非分泌性タンパク質の合成 は加粈で変化しないという，また，分必性タンパク質の 合成は低下するが，分泌タンパク質の SDS ゲルによる 電気泳動像には質的な差異は認められなかったという。 このととはSDS 電気泳動法に関する本実験結果と一致 する.

しかし肝臟では加㱓とともにアルブミンの合成が促進 し，フェリチン合成は変化しないが，へムタンパク質の 合成は低下すると報告80) されている，そして，てれら の変化は加粗に伴う細胞機能の変化のためであるてとが 示唆されている.ラット耳下腺では, 分泌タンパク質合 成の低下は細胞の代謝活性の低下, 形態的変化あるいは 細胞数の減少などの影響を受けないし，特殊なタンパク 
質成分のみが合成低下するのではないことが報告されて いるが，本実験では中年齢化で質的に出現したり，量的 に増量する画分が発見できた。てのととは特殊なタンパ 質成分の合成系が促進することを示唆している。しか しながら，加齢に伴って老化の兆候と思われるタンパク 質成分が出現したととが, 加齢に伴ら腺組織の脂肪化, 結合織化 ${ }^{24,25,52)}$ あるいは分泌タンパク質の合成能の 低下と関連するかどうかは現時点では不明である。

ヒト睡液のアミラーゼアイソザイムの分析は, 先人達 81により色々な方法で行われてきている. 現在では， $6 ， 7$ 種に分離されている.乙の 6,7 種が糖鎖をもた ない群と糖鎖の付加した群に分類されている，七下唾液 のアミラーゼアイソザイムの等電点は $\mathrm{pH} 5.22 ， 5.65$, $5.80 ， 5.80$ および 6.65 ，南るいは $\mathrm{pH} 5.80 ， 6.20$ ， $6.35 ， 6.65$ および6.90であるてとが報告811されている. ラットではヒトの場合と大きく異なり, $\mathrm{pH} \mathrm{4.23〜4.86}$ の等電点をもつ 4 種のアイソザイムが検出された．てれ らのアイソザイムは同一のタンパク質から由来し, タン パク質合成後にコルジー野で糖鎖が付加され 2 群にわか れる．各アイソザイムのアミノ酸組成は同じであり，お そらく一次構造も同じであろうと考元られている。てれ らのアイソザィムの生理的意義は現在も不明である.

アイソザィムパターンは $4{ }^{\circ} \mathrm{C}$ の短期間の貯蔵では変 化しないが, 長期間の貯蔵では各アイソザイムの量的比 が変化する. また，pH 8〜9で貯蔵すると1つのア1 ソザイムがもう1つのアイソザイムに変化するととがあ ると報告811されている。また，てれらのアイソザイム は遺伝的支配を受ける811．また，Chilla ら (1974) ${ }^{66)}$ は老歯ラットでは, アミラーゼ活性の比活性が相当に低 くなるが，乙の低下は 2 つのアソザイム活性の減少に 起囚するという。．さらに Murata ら（1986 $)^{511}$ による と導管結禁によるラット耳下腺の萎縮はアイソザイムパ ターンを変えるという. しかし, 本実験では各種の電気 泳動法を用いて検討したタンパク質成分の分析結果やア ミラーゼアイソザイムの検討結果は，アイソザィムパタ ーンが年齢，性別および刺激の種類で少なくとも質的に 変化するという所見は得られなかった，てれらの所見は 加路でタンパク質成分は変化しないという報告 ${ }^{26)}$ 之轨 を一つにする．しかし，本実験で用いだラットは最高齢 でも15月跉であったので，老齢（24月齢）化によりパタ ーンが変化するかどうかはわからなかった。しかし，交 感神経性 $\beta-\operatorname{Re}$ の機能は老齢化で変化しないといら報 告 $\left.{ }^{3}, 26\right)$ があるから， $\beta$ - $\operatorname{Re}$ 依存性成分のアミラーゼ アイソザイムが老粈化で質的に変化するとは考えられな
い.

西液のタンパク質成分のうちの高濃度画分は, さらに 高い分解能をもつ電気泳動法 (イモビライン) などで再 検討すると，複数の成分から構成されていたり，高プロ リンタンパク質成分のように染色性の極めて低い成分が 存在する可能性があるので, タンパク質成分の変化をア ミノ酸組成の分析からも検討した。 ラット耳下腺睡液の ア之ノ酸組成は，ヒトの場合 ${ }^{82}$ と類似していた。ての ことは，ヒト耳下腺唾液の場合には刺激差が認められな いという報告8 ${ }^{2}$ や成熟ラット耳下腺の場合に刺激薬の 投与量 ${ }^{22}$ や刺激の種類 23,63 ) でアミノ酸組成は大きく は変わらないという報告と一致した。 また，本実験のア ミノ酸組成の変化はタンパク質成分分泌の Parallelism と一致するものであった。また特殊な画分以外は，質 的に大きく異なる成分の重複化は少ない上うに思われ た。

\section{結 論}

加齢に伴亏交感神経性 $\alpha_{1}$ 一受容体（Re）之副交感神 経性 $\operatorname{Re} の$ 分泌機能の変化を明らかにするため, 幼若時 汃ら中年歯化至る雌雄ラット耳下腺汃ら交感神経性 $\alpha_{1}$ 一 Re および副交感神経性 $\operatorname{Re}$ 刺激薬により分泌する純 粋睡液を採取し，分析した。

実験動物には，4〜8の各週齢，10週龄，3.5月齢， 8 月齢抢よび15月齢の雌雄ラットを使用した。分泌刺激 薬には，交感神経性 $\alpha_{1}-\operatorname{Re}$ 刺激薬としてメトキサそ ン湓酸壏 (Methox) 副交感神経性 Re 刺激菂とし てピロカルピン塩酸塩（Pilo）を用いた。測定は, 分泌 唾液量, 液の分泌速度ならびに唾液中のタンパク質濃 度, アミラーゼ活性, $\mathrm{K} \cdot \mathrm{Ca} ・ \mathrm{Pi}$ 嶩度, タンパク質成 分, アミラーゼアイソザイムパターン, アミノ酸組成抒 よびレシン試験片付着タンパク質について行い，以下の 結果を得た。

1. 耳下腺の腺湿重量は, 雄では 8 週齢まで急増し, その後 3.5 月齢まで漸増したが，15月齢では減少した。 雌の場合では 3.5月齢まで漱増後, 15月齢で減少した。 倠雄とも3.5月齢までは体重の変化に順灾していたが， 15月齢では体重の動きと逆行した，腺湿重量の性差は体 重より 1 週龄遅れて 6 週龄より出現した。

2.耳下腺の分泌睡液量は Methox 刺激の場合には, 加㢼差および性差は認められなかったが，Pilo 刺激の 場合には，加秢差および性差が認められた。分泌喠液量 は年軨, 性別および刺激の種類に関係なく, 腺湿重量に 順相関した。 
3.タンパク質濃度には, 両刺激の雌雄とも, 加粭差 は得られなかったが，Pilo 刺激の場合には性差が恐め られた。両表示の分泌タンパク質量は，両刺激とも加齢 差抢よび性差を示した。また，タンパク質濃度は，年齢 や性別に関係なく, 分泌速度の速い時と遅い時とで, そ れぞれの速度に順あるいは逆相関した。

4.アミラーゼ活性には両刺激とも加齢差は認められ なかったが，Pilo刺激には性差が認められた。アミラー ゼ活性は, 年舲, 性別および刺激の種類に関係なく, 夕 ンパク質濃度に順相関した。また, 交感神経性 $\alpha_{1}-\mathrm{Re}$ 刺激唾液のアミラーゼ活性は $\mathrm{Ca}$ 濃度に順相関した。

5.K濃度には加噛差および性差は認められなかっ た。また，K濃度は年踰，性別および刺激の種類に関係 なく，睡液の分泌速度に逆相関した。

6. Ca 濃度には加歯差は認められなかった。しか し，性差は Methox 刺激には認められなかったが Pilo 刺激に認められた。

7. $\mathrm{Pi}$ 濃度には両刺激とも加齢差は認められなかっ たが，Methox 刺激の場合には性差が認められた。ま た, $\mathrm{Pi}$ 濃度は，年䒜，性別および刺激の種類に関係な く，比較的分泌速度の遅いときには圂液の分泌速度に逆 相関した。

8、唓液のタンパク質成分には大きな加秢差, 性差お よび刺激差は認められなかった。このことから，ラット 耳下腺のタンパク質成分分泌には 4 週路から15月齢に至 るまで Parallelism が維持されていることがわかっ た。しかし，8および15月齢の中年齢になると性別や刺 激の種類に関係なく，棰液中に特徽的なタンパク質を分 泌するラットが多くなった。
9、Methox およよひ Pilo 刺激睡液には pH 4.23， 4.58，4.71および4.86の等電点をもつ 4 種のアイソザイ ムが検出された。アミラーゼアイソザイムパターンにも 大きな加跉差，性差および刺激差は認められなかった。

10.アミノ酸組成にも大きな加齢差, 性差および刺激 差は認められなかった。

11. Re 遮断薬を Methox あるいは Pilo と組み合わ せるととによって, 自律神経系の分泌機能の加齢的変化 を検討した結果，いくらかの組み合わせにおいて全被験 年齢ラットの睡液分泌が完全に抑制された。

12.レシン試験片に付着する唾液のタンパク質成分は Pilo 刺激の場合, 電気泳動上, 移動度の大きいものが 多かった。また，鏡面仕上げ処理はタンパク質の付着を 抑制した。

各種パラメータの測定結果からラット耳下腺の交感神 経性 $\alpha_{1}-\operatorname{Re}$ 打上び副交感神経性 $\operatorname{Re} の$ 分泌機能は幼 若時に完成し，中年齢に至るまで不変であることが示唆 された。しかし，8〜15月齢になると，老化の兆候と思 われる異常タンパク質成分が悐められるようになった。

$$
\text { 謝辞 }
$$

稿を終るに臨み，終始御慧篤なる御指導，御校閲を賜 わった福岡霜科大学嵝科禣経学第一講座羽生哲也教授な らびに口腔生化学講座阿部公生教授に深甚なる感謝の意 を表します。また，常に適切なる御教示，御校閲を戴き ました九州歯科大学口腔生化学講座野口知雄教授に厚く 御礼申し上げます。なお有益なる御助言を戴きました九 州䨑科大学歯科補経学第一講座豊田静夫教授ならびに口 腔科学講座天野仁一朗教授に厚く御礼申し上げます。

\section{引用 文 献}

1) Ball, W.D. : Development of the rat salivary glands. 1. Accumulation of parotid gland DNase activity. J. Exp. Zool. $178: 331-342,1971$.

2) Redman, R.S. and Sreebny, L.M. : Proliferative behavior of differentiating cells in the developing rat parotid gland. J. Cell Biol. 46:81-87, 1970.

3) Redman, R.S. and Sreebny, L.M. : Morphologic and biochemical observations on the development of the rat parotid gland. Dev. Biol. $25: 248-279,1971$.

4) Schneyer, C.A. and Hall, H.D. : Growth pattern of postnatally developing rat parotid gland. Proc. Soc. Exp. Biol. Med. 130:603-607,1969.

5 ) Schneyer, C.A. and Hall, H.D. : Influence of physiological activity on mitosis in immature rat parotid gland. Proc. Soc. Exp. Biol. Med. 133:349-352, 1970 a.

6) Schneyer, C.A. : Regulation of salivary gland size (Ed. Goss, R.J.). Academic Press, New York, 1972, 211-232. 
7) Klein, R.M. : $\beta$-Adrenergic drug induced hyperplasia in the immature rat parotid and submandibular glands. Eur. J. Pharmacol. $105: 327-331,1984$.

8 ) Schneyer, C.A. and Hall, H.D. : Effects of denervation on development of function and structure of immature rat parotid. Am. J. Physiol. 212:871-876,1967.

9) Schneyer, C.A. and Hall, H.D. : Time course and autonomic regulation of development of secretory function of rat parotid. Am. J. Physiol. 214:808-813, 1968.

10) Schneyer, C.A. and Hall, H.D. : Autonomic regulation of postnatal changes in cell number and size of rat parotid. Am. J. Physiol. 219:1268-1272, $1970 \mathrm{~b}$.

11) Schneyer, C.A. and Hall, H.D. : Autonomic regulation of changes in rat parotid amylase during postnatal development. Am. J. Physiol. $223: 172-175,1972$.

12) Grand, R.J., Chong, D.A. and Ryan, S.J. : Postnatal development of adenylate cyclase in rat salivary glands: Patterns of hormonal sensitivity. Am. J. Physiol. 228:608-612, 1975.

13) Ludford, J.M. and Talamo, B.R. : $\beta$-Adrenergic and muscarinic receptors in developing rat parotid glands. J. Biol. Chem. $255: 4619-4627,1980$.

14) Grand, R.J. and Schay, M. I. : Development of secretory function in rat parotid gland. Pediat. Res. $12: 100-104,1978$.

15) Mangos, J.A. : Micropuncture study of postnatal functional maturation of the rat parotid. $J$. Dent. Res. $57: 826-833,1978$.

16) Abe, K. and Dawes, C. : Circadian variations in pilocarpine and isoprenaline-induced protein secretion by rat parotid gland. Archs. Oral Biol. 20:543-546, 1975.

17) Abe,K. and Dawes, C. : The effects of electrical and pharmacological stimulation on the types of proteins secreted by rat parotid and submandibular glands. Archs. Oral Biol. $23: 367-372,1978$.

18) Young, J.A., Cook, D.I., Jones, G., McGirr, J. and Thompson, C. : The effect of phenylephrine on excretion of fluid and electrolytes by the parotid and mandibular glands of the rat. AJEBAK. $57: 555-562,1979$.

19）阿部公生・及川 将・阿部成生・高田 登：ラット顎下腺の蛋白質分泌に及ぼすピロカルピンの作用. 岐粜 学誌 $10: 242-252,1982$.

20) Abe, K., Oikawa, M. and Abe, S. : Rate of protein excretion of rat submandibular and parotid saliva elicited by different stimuli. J. Gifu Dent. Soc. $10: 460-471,1983$.

21) Abe, K. and Dawes, C. : Dopamine-induced secretion of protein and of some electrolytes by rat submandibular and parotid glands. Archs. Oral Biol. $27: 635-643,1982$.

22) Abe, K. and Dawes, C. : The effects of $\alpha$-methylnoradrenaline on protein and electrolyte secretion by rat submandibular and parotid glands. Comp. Biochem. Physiol. 78C : 383389,1984 .

23) Abe, K. and Dawes, C. : The effects of oxymetazoline on secretion of protein and some electrolytes by rat submandibular and parotid glands. Comp. Biochem. Physiol. 80C : $347-353,1985$.

24) Andrew, W. : A comparison of age changes in salivary glands of man and of the rat. $J$. Gerontol. $7: 178-190,1952$.

25) Waterhouse, J.P., Chisholm, D.M., Winter, R.B., Pater, M. and Yale, R.S. : Replacement of functional parenchymal cells by fat and connective tissue in human submandibular salivary glands: An age-related change. J. Oral Path. 2:16-27, 1973. 
26) Ito, H., Baum, B.J. and Roth, G.S. : $\beta$-Adrenergic regulation of rat parotid gland exocrine protein secretion during aging. Mech. Ageing Dev. $15: 177-188,1981$.

27) Kim, S.K., Weinhold, P.A., Han, S.S. and Wagner, D.J. : Age-related decline in protein synthesis in the rat parotid gland. Exp. Geront. $15: 77-85,1980$.

28) Kim, S.K., Weinhold, P.A., Calkins, D.W. and Hartog, V.W. : Comparative studies of the age-related changes in protein synthesis in the rat pancreas and parotid gland. Exp. Geront. $16: 91-99,1981$ b.

29) Kim, S.K., Calkins, D.W., Weinhold, P.A. and Han, S.S. : Changes in the synthesis of exportable and nonexportable proteins in parotid glands during aging. Mech. Ageing Dev. $18: 239-250,1982$.

30) Kim, S.K. and Calkins, D.W. : Secretory protein synthesis in parotid glands of young and old rats. Archs. Oral Biol. $28: 1-4,1983$.

31) Kim, S.K. : Age-related changes in the cellular level of amylase and protein synthesis in the rat parotid gland. J. Dent. Res. 60:738-747, 1981a.

32) Ito, H., Hoopes, M.T., Roth, G.S. and Baum, B.J. : Adrenergic and cholinergic mediated glucose oxidation by rat parotid gland acinar cells during aging. Biochem. Biophys. Res. Com. $98: 275-282,1981$.

33) Ito, H., Baum, B.J., Uchida, T., Hoopes, M.T., Bodner, L. and Roth, G.S. : Modulation of rat parotid cell $\alpha$-adrenergic responsiveness at a step subsequent to receptor activation. J. Biol. Chem. $257: 9532-9538,1982$.

34) Bodner, L., Hoopes, M. T., Gee, M., Ito, H., Roth, G.S. and Baum, B.J.: Multiple transduction mechanisms are likely involved in calcium-mediated exocrine secretory events in rat parotid cells. J. Biol. Chem. 258:2774-2777, 1983.

35) Bellavia, S.L., Sanz, E.G., Vermouth, N.T., Rins, M.L. and Aoki, A.: Sex difference in the rate of postnatal development of amylase activity in the rat parotid gland. Archs. Oral Biol. $26: 59-60,1981$.

36) Klein, R.M. and Harrington, D. B. : Acinar cell cycle of developing rat parotid gland: Comparison of males and females. J. Dent. Res. $55: 712,1976$.

37) Baum, B.J. : Evaluation of stimulated parotid saliva flow rate in different age groups. $J$. Dent. Res. $60: 1292-1296,1981$ a.

38) Hand, A.R. and Ho, B. : Liquid-diet-induced alterations of rat parotid acinar cells studied by electron microscopy and enzyme cytochemistry. Archs. Oral Biol. $26: 369-380,1981$.

39) Johnson, D.A. and Sreebny, L.M. : Effect of increasing the bulk content of the diet on the rat parotid gland and saliva. J. Dent. Res. 61:691-696, 1982 .

40) Hioki, S., Matsumoto, M., Mitsui, S., Oikawa, M., Abe, S., Takada, N. and Abe, K.: The effects of incisal bite plane on rat parotid glands. J. Gifu Dent. Soc. 9:293-304, 1981 .

41）村田篤彦：ラット 3 大唾液腺に及ぼす两側下顎切菡切断の影響. 岐歯学誌 $9: 40$ 一6, 1981.

42）鴨頭和利：上顎側方拡大装置のラット顎下腺および舌下腺に及ぼす影響. 九州荬会誌 $41: 233$ 一 256 ，1987.

43) Lowry, O.H., Rosebrough, N.J., Farr, A.L. and Randall, R.J. : Protein measurement with Folin phenol reagent. J. Biol. Chem. $193: 265-275,1951$.

44) Dawes, C. : Some characteristics of parotid and submandibular salivary proteins. Archs. Oral Biol. $10: 269-279,1965$.

45）早川哲夫・戸田安士・仁川正一・服部 正・野田愛司・菊池三郎：Amylase test Daiichi 法, Remazol 
brilliant blue R starch 法, および Caraway 法による膵および睡液アミラーゼの基質特異性. 日本 消化器病学会誌 $69: 143-147,1972$.

46) Dawes, C. : The secretion of magnesium and calcium in human parotid saliva. Caries Res. $1: 333-342,1967$.

47) Dawes, C. : The effects of flow rate and duration of stimulation on the concentrations of protein and the main electrolytes in human parotid saliva. Archs. Oral Biol. 14:277$294,1969$.

48) Chen, P.S., Toribara, T.Y. and Warner, H. : Microdetermination of phosphorus. Analyt. Chem. $28: 1756-1758,1956$.

49) Dawes, C. : Disodium ethylenediaminetetraacetate as an aid for the reconstitution of lyophilized human salivary proteins before paper electrophoresis. Archs. Oral Biol. 8:653656, 1963 .

50) Kapitany, R.A. and Zebrowski, E.J. : A high resolution PAS stain for polyacrylamide gel electrophoresis. Analyt. Biochem. $56: 361-369,1973$.

51) Murata, K., Ikeno, T. and Kuzuya, H. : Ligation of the parotid duct changes zymograms of amylase isozymes in the parotid gland and the serum of rats. Jpn. J. Oral Biol. 28 : 229-232, 1986.

52) Baum, B.J. : Research on aging and oral health : An assessment of current status and future needs. Spec. Care Dent. 1:156-161, 1981b.

53) Grzegorczyk, P.B., Jones, S.W. and Mistretta, C.M. : Age-related differences in salt taste acuity. J. Gerontol. $34: 834-840,1979$.

54) Scott, J. : Age, sex and contralateral differences in the volumes of human submandibular salivary glands. Archs. Oral Biol. 20:885-887, 1975.

55）阿部成生：幼弱ラット顎下腺の交感神経性 $\alpha_{1}$ 一受容体機能の加踰変化にみられる性差. 㐘基儊誌 $27: 909$ $-932,1985$.

56) Abe, K., Hidaka, S., Ishibashi, K., Yanabu, M., Kamogashira, K., Itoh, T. and Matsumoto, M. : Developmental changes in the volumes, protein and some electrolyte concentrations of male and female rat submandibular saliva secreted in response to methoxamine and pilocarpine. J. Dent. Res. $66:$ In Press, 1987.

57) Dawes, C. and Shaw, J.H. : The effects of changes in the proportion and type of dietary carbohydrate on the amylase and protein concentrations in rat saliva. Archs. Oral Biol. $10: 261-267,1965$.

58) Ericson, S., Hedin, M. and Wiberg, A. : Variability of the submandibular flow rate in man with special reference to the size of the gland. Odont. Revy $23: 411-420,1972$.

59) Dawes, C., Cross, H.G., Baker, C.G. and Chebib, F.S. : The influence of gland size on the flow rate and composition of human parotid saliva. J. Canad. Dent. Ass. $44: 21-25$, 1978.

60) Matthews, R.W. : The effects of autonomic stimulation upon the rat submandibular glands. Archs. Oral Biol. 19:989-994, 1974.

61) Gutman, D. and Ben-Aryeh, H. : The influence of age on salivary content and rate of flow. Int. J. Oral Surg. 3:314-317, 1974.

62) Sreebny, L.M., Johnson, D.A. and Robinovitch, M.R. : Functional regulation of protein synthesis in the rat parotid gland. J. Biol. Chem. 246:3879-3884, 1971.

63) Abe, K. and Nitta, H. : Amino acid composition of salivary protein secreted by the parotid 
glands of rats in response to parasympathomimetic and sympathomimetic drugs. Archs. Oral Biol. 29:127-130, 1984.

64) Leslie, B.A., Putney, J.W. and Sherman, J.M. : $\alpha$-Adrenergic, $\beta$-adrenergic and cholinergic mechanisms for amylase secretion by rat parotid gland in vitro. $J$. Physiol. 260:351370,1976 .

65) Schneyer, C.A. and Hall, H.D. : Comparison of rat salivas evoked by auriculo-temporal and pilocarpine stimulation. Am. J. Physiol. 209:484-488, 1965.

66) Chilla, R., Niemann, H., Arglebe, C. and Domagk, G.F.: Age-dependent changes in the $\alpha$-isoamylase pattern of human and rat parotid glands. ORL. $36: 373-382,1974$.

67) Blomfield, J., Rush, A.R. and Allars, H.M. : Interrelationships between flow rate, amylase, calcium, sodium, potassium and inorganic phosphate in stimulated human parotid saliva. Archs. Oral Biol. 21:645-650, 1976.

68) Schneyer, C.A., Sucanthapree, C. and Schneyer, L.H. : Neural regulation of calcium and amylase of rat parotid saliva. Proc. Soc. Exp. Biol. Med. $156: 132-135,1977$.

69) Schneyer, C.A., Sucanthapree, C., Schneyer, L.H. and Jirakulsomchok, D. : Total salivary calcium and amylase output of rat parotid with electrical stimulation of autonomic innervation. Proc. Soc. Exp. Biol. Med. 159:478-483, 1978.

70) Windeler, A.S. and Shannon, I.L. : The effect of flow rate on parotid fluid calcium and protein levels. Archs. Oral Biol. 11: 1043-1045, 1966.

71) Wainwright, W.W. : Human saliva. XV. Inorganic phosphorus content of resting saliva of 650 healthy individuals. J. Dent. Res. 22:403-414, 1943.

72) Maier, H., Coroneo, M. T., Antonczyk, G. and Heidland, A. : The flow-rate-dependent excretion of ionized calcium in human parotid saliva. Archs. Oral Biol. 24:225-227, 1979.

73) Putney, J.W.: Muscarinic, alpha-adrenergic and peptide receptors regulate the same calcium influx sites in the parotid gland. J. Physiol. $268: 139-149,1977$.

74) Petersen, O.H. and Maruyama, Y. : Calcium-activated potassium channels and their role in secretion. Nature $307: 693-696,1984$.

75) Dische, Z., Kahn, N., Rothschild, C., Danilchenko, A., Licking, J. and Wang, S.C.: Glycoproteins of submaxillary saliva of the cat. Differences in composition produced by sympathetic and parasympathetic nerve stimulation. J. Neurochem. $17: 649-658,1970$.

76) Dawes, C. : The effects of exercise on protein and electrolyte secretion in parotid saliva. $J$. Physiol. $320: 139-148,1981$.

77) Dawes, C. : Stimulus effects on protein and electrolyte concentrations in parotid saliva. $J$. Physiol. $346: 579-588,1984$.

78) Gilliland, E.L. and Glazer, G.: Parallel secretion of enzymes by the rabbit pancreas. $J$. Physiol. $303: 33-41,1980$.

79) Dagorn, J.C. : Non-parallel enzyme secretion from rat pancreas: in vivo studies. J. Physiol. $280: 435-448,1978$.

80) Beauchene, R.E., Roeder, L.M. and Barrows, C.H. : The interrelationships of age, tissue protein synthesis, and proteinuria. J. Gerontol. $25: 359-363,1970$.

81) Merritt, A.D. and Karn, R.C. : The human $\alpha$-amylases. Adv. Hum. Genet. 8:135-234, 1971 .

82) Feller, R.P., Shannon, I.L. and Wescott, W.B. : Total amino acid levels of parotid saliva at different rates of gland function. J. Dent. Res. $53: 772,1974$. 